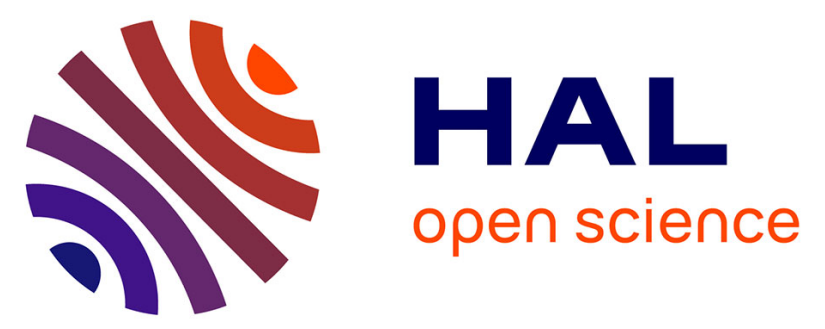

\title{
Revised chronostratigraphy of recurrent ignimbritic eruptions in Dominica (Lesser Antilles Arc): Implications on the behavior of the magma plumbing system
}

\author{
Georges Boudon, Hélène Balcone-Boissard, Clara Solaro, Caroline Martel
}

\section{To cite this version:}

Georges Boudon, Hélène Balcone-Boissard, Clara Solaro, Caroline Martel. Revised chronostratigraphy of recurrent ignimbritic eruptions in Dominica (Lesser Antilles Arc): Implications on the behavior of the magma plumbing system. Journal of Volcanology and Geothermal Research, 2017, 343, pp.135154. 10.1016/j.jvolgeores.2017.06.022 . insu-01557350

\section{HAL Id: insu-01557350 \\ https://hal-insu.archives-ouvertes.fr/insu-01557350}

Submitted on 6 Jul 2017

HAL is a multi-disciplinary open access archive for the deposit and dissemination of scientific research documents, whether they are published or not. The documents may come from teaching and research institutions in France or abroad, or from public or private research centers.
L'archive ouverte pluridisciplinaire HAL, est destinée au dépôt et à la diffusion de documents scientifiques de niveau recherche, publiés ou non, émanant des établissements d'enseignement et de recherche français ou étrangers, des laboratoires publics ou privés.

\section{(1) (1) $\$$}

Distributed under a Creative Commons Attribution - NonCommercial - NoDerivatives 44.0 


\section{Accepted Manuscript}

Revised chronostratigraphy of recurrent ignimbritic eruptions in Dominica (Lesser Antilles Arc): Implications on the behavior of the magma plumbing system

Georges Boudon, Hélène Balcone-Boissard, Clara Solaro, Caroline Martel

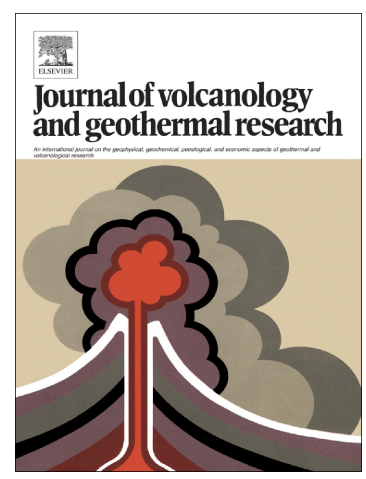

PII: S0377-0273(17)30162-2

DOI: doi: 10.1016/j.jvolgeores.2017.06.022

Reference: VOLGEO 6143

To appear in: Journal of Volcanology and Geothermal Research

Received date: $\quad 14$ March 2017

Revised date: 7 June 2017

Accepted date: 12 June 2017

Please cite this article as: Georges Boudon, Hélène Balcone-Boissard, Clara Solaro, Caroline Martel , Revised chronostratigraphy of recurrent ignimbritic eruptions in Dominica (Lesser Antilles Arc): Implications on the behavior of the magma plumbing system, Journal of Volcanology and Geothermal Research (2017), doi: 10.1016/ j.jvolgeores.2017.06.022

This is a PDF file of an unedited manuscript that has been accepted for publication. As a service to our customers we are providing this early version of the manuscript. The manuscript will undergo copyediting, typesetting, and review of the resulting proof before it is published in its final form. Please note that during the production process errors may be discovered which could affect the content, and all legal disclaimers that apply to the journal pertain. 
Revised chronostratigraphy of recurrent ignimbritic eruptions in Dominica

(Lesser Antilles Arc): Implications on the behavior of the magma plumbing system

Georges Boudon $^{\mathrm{a}}$, Hélène Balcone-Boissard ${ }^{\mathrm{b}}$, Clara Solaro $^{\mathrm{a}}$, Caroline Martel ${ }^{\mathrm{c}}$

${ }^{a}$ Institut de Physique du Globe de Paris, Sorbonne Paris Cité, Univ. Paris Diderot, CNRS, F75005 Paris, (France)

${ }^{b}$ Sorbonne Universités, UPMC Univ. Paris 06, CNRS, UMR 7193, ISTeP, F-75005, Paris,

(France)

'Institut des Sciences de la Terre d'Orléans (ISTO), UMR 7327 Université d'Orléans-CNRSBRGM, Orléans, (France).

To be submitted to JVGR

Keywords: Dominica, ignimbrites, stratigraphy, ${ }^{14} \mathrm{C}$ dating, lithology, geochemistry 


\section{ABSTRACT}

Ignimbritic eruptions represent catastrophic events due to the magma volume involved and the related consequences on Earth's environment in relation with the released gases and the tephra dispersal. Dominica has been recognized as hosting one of the major ignimbritic eruptions of the last $200 \mathrm{ky}$ in the Lesser Antilles arc, called the Roseau Tuff. But more recent works have evidenced several pumiceous events instead of a single large one. Here we propose a revised chronostratigraphy of the explosive activity that occurred in the last tens of thousands years based on three field trips, new ${ }^{14} \mathrm{C}$ ages, detailed lithological and geochemical investigations, in particular a precise characterization of trace element glass chemistry. This eruptive history reconstruction is mainly based on outcrops along the coast and in the valley, since the luxury vegetation in the center of the island mostly precludes sections close to the central volcanic centers. We thus confirm that the Roseau event has been overestimated and that we may recognize five main ignimbritic events: Grande Savane, Layou ( 51 ka), Grand Bay, Roseau ( 33 ka), Grand Fond ( 24 ka). We discuss the possible volcanic center at their origin, in addition to correlations with some Plinian events of lower magnitude that were identified in the Roseau valley and in the southern part of Dominica. This study may help to better constrain the eruptive history of the most active volcanic island of the Lesser Antilles arc, which has important implications on hazard mitigation. 


\section{Introduction}

Ignimbritic eruptions when they occur may have a dramatic effect not only due to the magma volume involved (order of magnitude of one to tens of $\mathrm{km}^{3}$ ) but also because of their related consequences (tephra dispersal, climatic effect) on the Earth's environment across various temporal and space scales. In the last thousand years, few large ignimbritic eruptions have occurred. During the Minoan eruption of Santorini volcano (Greece; 3600 yrs BP) 20-30 $\mathrm{km}^{3}$ DRE was emitted and was responsible of the disappearance of the Minoan civilization (Bond and Sparks, 1976; (Johnston et al., 2014; Sigurdsson et al., 2006). For the 1257 AD Samalas eruption on Lombok island (Indonesia) $40 \mathrm{~km}^{3}$ DRE was emplaced; it has been recently recognized as an important chronostratigraphic marker through a sulfate peak identified in the polar ice core (Lavigne et al., 2013; Vidal et al., 2016). More recently, during the 1815 Tambora eruption (Indonesia) about $50 \mathrm{~km}^{3}$ DRE were emitted, and significantly impacted the climate, in particular the following year "without summer" in the northern hemisphere (Self et al., 1984). Finally, the 1991 Pinatubo eruption (Philippines) was the largest eruption of the last decades with the emission of $\sim 5 \mathrm{~km}^{3}$ DRE, involving a global temperature drop by about $0.5^{\circ} \mathrm{C}$ in the years $1991-1993$ (Self et al., 1993).

In the Lesser Antilles arc, the volume of magma involved in most of the eruptions along the volcanic arc is relatively low (generally $<0.5 \mathrm{~km}^{3}$ ) as evidenced by many historical and prehistorical eruptions (Lindsay et al., 2005a). During the dome-forming eruptions of 19021905 and 1929-1932 of Montagne Pelée (Martinique) 0.2-0.3 $\mathrm{km}^{3}$ was erupted (Tanguy, 2004a). Less than $0.2 \mathrm{~km}^{3}$ of magma was erupted during the successive explosive and lava dome-forming eruptions of Soufrière of St. Vincent in 1902-1903, 1971 and 1979, and the magma involved in each of the numerous submarine eruptions of Kick'em Jenny volcano is very low (probably less than $0.05-0.1 \mathrm{~km}^{3}$ ). The recent and long lava dome-forming eruption 
of Soufrière Hills at Montserrat (1995-2010) is an exception as in the order of $1 \mathrm{~km}^{3}$ DRE was erupted (Wadge et al., 2010). But these volumes are low compared with the magma emitted at Dominica during the last tens of thousands years.

The pioneer works on the island recognized a voluminous ignimbritic eruption called "the Roseau Tuff'(Sigurdsson, 1972; Carey and Sigurdsson, 1980). This eruption, dated between 50 and $30 \mathrm{ka}$, has been thought to be responsible for the emission of $\sim 58 \mathrm{~km}^{3}$ DRE, leading on-land to thick deposits of pumiceous pyroclastic density currents (PDC), welded in some places, and offshore by tephra fallout and by turbiditic deposits in the Grenada Basin. Recent stratigraphical investigations have evidenced that these thick deposits belonged not to a unique event but to a series of 7 eruptions dated between 50 and $20 \mathrm{ka}$ (Howe et al., 2015b, 2014; Smith et al., 2013). Although the volume of the emitted products per eruption is lower than previously proposed, it still contrasts with the common estimation along the Lesser Antilles arc. Dominica is thus characterized in the last tens of thousands years by infrequent large pumiceous eruptions whereas in the same period of time, several small pumiceous eruptions (generally $<0.5 \mathrm{~km}^{3}$ ) (Carazzo et al., 2012; Legendre, 2012) occurred on the neighboring islands of Guadeloupe and Martinique. In addition, whereas most islands of the Lesser Antilles arc only evidence one active volcano, Dominica exhibits the particularity of 4 large active volcanic centers and several others of lower of lower volume (Lindsay et al., 2005b). Dominica and the neighboring islands of Guadeloupe and Martinique concentrate half of the active volcanoes of the arc within its central part, only accounting for $1 / 5$ of its total length (Fig. 1). Thus Dominica volcanism raises the question of the genesis, storage, and eruption of such large volume of magma in a short period of time.

One key starting point is to clarify the spatial and temporal relationships between the different pumiceous deposits which have not been clearly established until now. We carried out three field trips in Dominica since 2011 to study the pumiceous eruptions, focusing on 
those that occurred in the central part of the island. On the basis of these recent on-land investigations, together with new ${ }^{14} \mathrm{C}$ dating on charcoals and detailed petrological and geochemical data on pumice glass, we propose here a revised chronostratigraphy of the pumiceous eruptions in the last tens of thousands years.

\section{Geological setting}

\subsection{The Lesser Antilles arc}

Dominica belongs to the Lesser Antilles arc which extends from $12^{\circ}$ to $18^{\circ} \mathrm{N}$ with a particular convexity to the East (Fig. 1). Active since the late Miocene, the Lesser Antilles arc consists of 11 volcanic islands and marks the westward subduction of the North American Plate beneath the Caribbean Plate. Convergence is estimated at $\sim 2 \mathrm{~cm} /$ year and is associated with a low arc magma production rate of $\sim 3 \mathrm{~km}^{3} / \mathrm{My}$ (Wadge, 1984; Wadge and Shepherd, 1984). North of Dominica, the arc is divided into two groups of islands. In the outer and older arc, volcanoes are extinct and, on several islands, covered by a thick carbonate platform (Fig. 1). Active volcanoes are located in the inner arc and have been active since $20 \mathrm{Ma}$. From Dominica to the South, the two branches of the arc merge and deposits of the older arc underlie the recent one. This southern part of the arc is bordered to the west by the $3000 \mathrm{~m}$ deep back-arc Grenada Basin. Active volcanoes are located on the younger part of the arc (Saba, St Eustatius, Nevis, St. Kitts, Montserrat, Guadeloupe, Dominica, Martinique, St. Lucia, St. Vincent and Grenada).

Dominica is the sole island of the arc that contains four large active volcanic centers: from North to South, Morne aux Diables where a seismic crisis occurred in 2010, Morne Diablotins, Morne Trois Pitons-Micotrin and Plat Pays Volcanic Complex (PPVC) (Fig. 2a). 
Small satellite centers are also present south of Morne Trois Pitons-Micotrin. The island is thus volcanically the most productive and potentially hazardous island of the Lesser Antilles arc. It is characterized by dominantly Pleistocene to recent volcanism. In the early Pleistocene (2-1.7 Ma), volcanism was limited to the northern half of Dominica and led to the development of Morne Diablotins, a large stratovolcano, and Morne aux Diables, a smaller lava dome complex (Smith et al., 2013). During the late Pleistocene (1.1-0 Ma), Morne Trois Pitons-Micotrin and the Plat Pays Volcanic Complex (PPVC) developed; in parallel, three smaller volcanic centers in the southern flank of Morne Trois Pitons-Micotrin were also active, namely Watt Mountain, Morne Anglais, Grande Soufrière Hills. PPVC is the only well-studied volcanic center on the south-western part of the island (Gurenko et al., 2005; Halama et al., 2006; Le Friant et al., 2002; Lindsay et al., 2005b, 2005c, 2003; Wadge, 1985). Although this time period has been dominated by lava dome-forming eruptions, similar to the ongoing eruption of Soufrière Hills on Montserrat, large recent ignimbritic deposits crop out across the island (Lindsay et al., 2005b; Smith et al., 2013). The last magmatic activity occurred on the PPVC with the building of the Morne Patate lava dome dated at $450 \pm 90 \mathrm{yrs}$. BP (Roobol et al., 1983). The Valley of Desolation within the Morne Trois Pitons - Micotrin volcanic center was the location of two historical phreatic eruptions in 1880 , and more recently in 1997 in the Boiling lake area (Fournier et al., 2009).

\subsection{Previous work on Dominica ignimbritic eruptions}

During the last tens of thousands years voluminous ignimbritic deposits were emitted in the central area of Dominica originated from Morne Trois Pitons-Micotrin and Morne Diablotins (Figs. 1, 2). 


\subsubsection{Roseau ignimbrite}

Sigurdsson (1972) identified firstly an ignimbritic deposit (the "Roseau tuff" eruption), 3 $\mathrm{km}^{3}$ in volume, welded in some parts, that filled the Roseau valley. The age proposed for the most voluminous deposits was between $28400 \pm 900 \mathrm{yr} \mathrm{BP}$ and $46000 \pm 4500 \mathrm{yr} \mathrm{BP}\left({ }^{14} \mathrm{C}\right.$ dating). Based on a tephrostratigraphic study on a series of piston cores sampled off Dominica, Carey and Sigurdsson (1980) identified extensive and recent marine pumiceous deposits that they correlated with the Roseau tuff. The total volume of the deposits of the Roseau tuff was estimated at $58 \mathrm{~km}^{3}$, divided into $3 \mathrm{~km}^{3}$ identified on-land, $25 \mathrm{~km}^{3}$ of tephra distributed to the Western Atlantic Ocean and $30 \mathrm{~km}^{3}$ of subaqueous debris flows deposited to the West on the floor of the back-arc Grenada Basin. Witham (1989) carried a detailed study on the turbiditic deposits associated to the Roseau tuff in the Grenada Basin (to which he included the ignimbritic deposits that filled on-land the Layou valley).

Smith et al. (2013) suggested that the Roseau tuff deposit likely represents material from seven separate Plinian eruptions showing clear time gaps between each other ( $>16 \mathrm{ky}$, from 30 to $>46 \mathrm{ky}$ cal BP, with many ages not overlapping within uncertainty). On the basis of (UTh)/He ages, Howe et al. (2014) proposed ages between 61 - 24 ka for a series of units referred as the "Roseau Sequence", but with poor constraints on the relationships between the different deposits in the Roseau valley. Carey and Sigurdsson (1980) considered that the Grand Fond ignimbritic deposits are part of the Roseau tuff with ages between $30000 \pm 1220$ and $36800 \pm 8079$ yr cal BP.

The vent at the origin of the Roseau Tuff has also been a matter of debate. Sigurdsson (1972) suggested the large dome complex of Micotrin volcano as the source of the eruptive sequence. Carey and Sigurdsson (1980), however, noted that the calculated volume of the basal Roseau Tuff eruption was too large to be contained into the Micotrin dome complex, which may indicate the existence of a caldera. (Demange et al., 1985) proposed a caldera at 
Wotten Waven, which is now mostly buried beneath Micotrin volcano. Therefore, Wotten Waven has been considered to be the likely source of the Roseau Tuff eruption (Lindsay et al., 2005b; Smith et al., 2013).

\subsubsection{Grand Bay ignimbrite}

The Grand Bay Ignimbrite is a laterally extended pumiceous PDC deposit that crops out along the southern coast of Dominica (Lindsay et al., 2003) in the area of Grand Bay and Geneva. Although Smith et al. (2013) suggested that the Grand Bay deposits were part of the Roseau Tuff Sequence based on overlapping whole rock geochemistry, Lindsay et al. (2003) ruled out such a correlation based on mineralogical and topographic constraints. Originally, the PPVC was considered as the source of the Grand Bay Ignimbrite (Lindsay et al., 2003), but more recent works proposed the Wotten Waven caldera as a possible eruptive center (Lindsay et al., 2005b, Smith et al., 2013). An age of $62.6 \pm 4$ ka was obtained by Howe et al. (2014) (U-Th/He apatite age).

\subsubsection{Layou ignimbrite}

The Layou PDC deposits which crop out within the confines of the Layou valley is thought to be sourced from the Morne Trois Pitons volcanic center (Smith et al., 2013). An age of $65 \pm 5 \mathrm{ka}$ is proposed by Howe et al. (2014) (U-Th/He zircon age) which is consistent with the ${ }^{14} \mathrm{C}$ minimum age of $>40 \mathrm{kyr}$ cal BP (Wadge, 1989).

\subsubsection{Grande Savane ignimbrite}

Sparks et al. (1980) showed that the Grande Savane fan is made of ignimbritic deposits welded in their lower part. The welded ignimbritic deposits forming high cliffs in the proximal valleys and a large submarine fan offshore indicate that a large part of the ignimbrite 
flowed under the sea. The unique age, obtained in a pumiceous surge deposit within the upper sequence, is $>22 \mathrm{ka}$ (Sparks et al., 1980).

\subsubsection{The Wesley/Londonderry ignimbrite}

The Wesley/Londonderry PDC is located on the northeastern side of the island (Sparks et al., 1980). The pyroclastic flow deposits at Londonderry beach were recently re-mapped as the Wesley pyroclastic flow fan (Smith et al., 2013, Howe et al., 2014, 2015a). The Wesley flow fan can be subdivided into two eruptive units separated by a thin paleosol (Smith et al., 2013). An age of $80 \pm 8 \mathrm{ka}$ was proposed by Howe et al. (2015; U-Th/He zircon age).

\subsubsection{Present lava domes}

The summit part of the volcanic centers of Morne Diablotins and Morne Trois PitonsMicotrin, from which the ignimbrites probably originated, is now occupied by voluminous lava domes. The Morne Trois Pitons consists of a voluminous lava dome complex with associated block-and ash-flow deposits. Micotrin lava dome is less voluminous, located in the south of Morne Trois Pitons. Dating of block-and ash-flow deposits associated to these lava domes provide large time bracket between $877 \pm 108$ and $28844 \pm 1983 \mathrm{yr}$ cal BP $\left({ }^{14} \mathrm{C}\right.$ dating, (Lindsay et al., 2005b). For Morne Diablotins, a minimum ${ }^{14} \mathrm{C}$ age of $>46 \mathrm{ka}$ was proposed by Smith et al. (2013) which is consistent with an U-Th/He age of $75 \pm 4$ ka given by (Howe et al., 2015b, 2014).

\section{Methodology}

\subsection{Fieldwork}


A series of three field trips were carried out in Dominica between 2011 and 2015 dedicated to the study of the pumiceous eruptions (Fig. 2). The central part of the island being covered by a dense rainy forest, only sea cliffs, large valleys, quarries and some roadsides offer the opportunity to study the pumiceous deposits. The different deposits are consequently disseminated in different sites (Fig. 2, Table 1). A detailed stratigraphy was established on the basis of field observations (textural and structural characteristics, thickness, grain size of the deposits...). The PDC and fallout deposits (pumices and matrix) were systematically wholly sampled for laboratory analysis. Considering the thickness of the PDC deposits, samples were picked within the base and the upper top of the accessible sequence, in addition to samples within different parts depending on the identified unit or degree of welding. Charcoals and paleosols were also sampled when present (Fig. 2).

\subsection{Lithology}

Samples from the different pumiceous PDC and fallout deposits were dried, weighted and sieved; the different fractions were washed in an ultrasonic bath and quartered. Lithologic counting was made in three different fractions $(0.500-1 \mathrm{~mm} ; 0.250-0.500 \mathrm{~mm} ; 0.125-0.250$ $\mathrm{mm}$ ) on a basis of a minimum of 500 clasts per fraction. Each component was identified and counted: crystals (feldspars, orthopyroxenes, clinopyroxenes, amphiboles, quartz, Fe-Ti oxides), pumice clasts, accidental clasts (lava dome or hydrothermal and oxidized clasts). The proportion of the different components in well-identified deposits serves as a criterion to correlate deposits that could not be correlated on a basis of field mapping.

\subsection{Dating}


Ages were determined on 14 charcoals and 8 paleosols using an accelerator mass spectrometry (AMS) at the LMC14 (Artemis, Laboratoire de Mesure du Carbone 14, CEA Saclay, France). The ages obtained were calibrated using the free software OxCal (OxCal 4.2, Bronk Ramsey, 2009) with the atmospheric IntCal13 calibration curve, recommended for the Northern Hemisphere (Reimer, 2013). OxCal is a software designed for the analysis of chronological information that we used to calculate the age probability distribution for each dated sample through radiocarbon calibration and, also more specifically here, to analyze groups of ages from stratigraphically-related deposits (i.e., the ages of stratigraphicallyconstrained samples of the same eruption are validated by using the R_Combine function and the $\chi^{2}$ test prior to calibration) (Ward and Wilson, 1978).

\subsection{Geochemistry}

For geochemical investigations, a part of the pumice and lava dome clasts was finely grinded for whole rock analyses. Another part of the pumice clasts was gently crushed, sieved for picking under binocular microscope the residual glass $(\sim 10 \mu \mathrm{g}$ in the fraction $125-250 \mu \mathrm{m}$ to obtain glass without crystals) and the minerals (feldspars, orthopyroxenes, clinopyroxenes, amphiboles, Fe-Ti oxides). The crystals and some residual glass chips were also mounted in epoxy resin and polished for point analyses.

Major elements on selected pumice and lava dome powders were analyzed by ICP-OES (Inductively Coupled Plasma-Optical Emission Spectrometry) (Carignan et al., 2001) at CRPG (Centre de Recherches Pétrographiques et Géochimiques, Nancy, France). Major elements ( $\mathrm{Si}, \mathrm{Ti}, \mathrm{Al}, \mathrm{Fe}, \mathrm{Mg}, \mathrm{Mn}, \mathrm{Ca}, \mathrm{Na}, \mathrm{K}, \mathrm{P}$ ) of minerals and residual glasses from pumice clasts were determined using electronic microprobe (EMPA, CAMECA SXFive, Camparis, France) with an acceleration voltage of $15 \mathrm{kV}$, a beam current of $4 \mathrm{nA}$ for major elements and 
a counting time of $5 \mathrm{~s}$ for $\mathrm{Si}$ and $\mathrm{Na}$ to limit $\mathrm{Na}$ loss and $10 \mathrm{~s}$ for the other elements. For intercalibration of each EMPA session, three natural glass samples used as internal standard were analyzed (obsidians from Lipari, Eolian Island, Italy; Little Glass Mountain, California, United States; and Corbetti volcano, Ethiopia) (Balcone-Boissard et al., 2008).

Trace element concentrations of whole-rocks, separated residual glasses and minerals were measured using an Agilent 7900 ICP-QMS (Inductively Coupled Plasma, Quadrupole Mass Spectrometry; IPGP France) in low resolution mode. Sample introduction was achieved with a micro-nebulizer (MicroMist, $0.2 \mathrm{ml} / \mathrm{min}$ ) through a Scott spray chamber. Except for lithium, elements below mass 80 were measured using a collision-reaction interface with helium gas $(5 \mathrm{ml} / \mathrm{min})$ to remove polyatomic interferences. A count to concentrations conversion was done using the BHVO-2 (basalt; Jochum et al., 2016) that was also used to assess the analytical drift of the ICP-QMS.

\section{Results}

\subsection{Stratigraphy}

The fieldwork first aims at identifying the main ignimbritic deposits (Fig. 2). This work mainly focuses on the voluminous deposits filling the main valleys on the western and eastern coasts, but other pumiceous deposits from explosive eruptions of lower magnitude were also identified and will be discussed. Benefitting from the previous fieldworks and in light of new outcrops, we were able to establish new field correlations and propose a revision of the stratigraphy.

\subsubsection{The Roseau sections}


In the lower part of the Roseau valley several outcrops and quarries allow to study pumiceous deposits; among them two main quarries give the opportunity to describe and sample a thick sequence of deposits: the "Goodwill" quarry (type locality for the "Roseau Tuff" eruption) described by Sigurdsson (1972) and the "Cocoyer Estate" quarry (Figs. 2b, 3a).

In the "Cocoyer Estate" quarry (location 1; Figs. 2, 3, 4d, e), a thick sequence of pumiceous deposits $(>50 \mathrm{~m})$ covers a paleosol formed in pebble-rich fluviatile deposits. The base of the volcanic deposit shows a fine-grained (ash and sand) fallout unit covered by a 30 $\mathrm{cm}$ thick pumice fallout deposit. This first sequence is covered by two $2 \mathrm{~m}$ thick ash-and pumice-PDC deposits, with a dominant proportion of small pumices $(<10 \mathrm{~cm})$, topped by a $15 \mathrm{~cm}$ thick Plinian fallout deposit. Above this Plinian deposit, there is a $40 \mathrm{~m}$ thick sequence of ash-and pumice-PDC deposits, finally covered by mature paleosols and reworked deposits. In the Goodwill Quarry (location 2; Figs. 2b, 3a, b) the paleosol at the top of thick sequence of pumiceous deposits is covered by three plinian deposits separated by paleosols. The first one is a massive, $1.25 \mathrm{~m}$ thick Plinian fallout deposit, hereafter referred as PPR1 (for 'Plinian Post-Roseau'); its upper part is modified by a thick paleosol. The second one is also a Plinian fallout deposit, $1.75 \mathrm{~m}$ thick, showing a succession of fine- and coarse-grained beds, hereafter referred as PPR2, topped by a thick paleosol. The last one is also a Plinian fallout deposit, 47 $\mathrm{cm}$ thick, showing at its base a succession of fine-grained beds, hereafter referred as PPR3. This deposit is covered by a sequence of $2 \mathrm{~m}$ thick reworked deposits.

Before the entrance of the Goodwill quarry (location 3; Figs. 2b, 3b), a 1.35 m thick, slightly stratified, pumice fallout deposit is covered by a few meter thick ash-and pumicePDC deposit, hereafter referred as 'Goodwill entrance'. This Plinian deposit covers a paleosol developed on the ash-and pumice-PDC described inside the Goodwill quarry. On the right bank of the Roseau river (right bank, roundabout: location 4; Figs. 2b, 3b), two Plinian fallout 
deposits (30 and $15 \mathrm{~cm}$ thick) are intercalated in a sequence of ash-and pumice-PDC deposits. The basal PDC deposit is rich in large pumice clasts (up to $80 \mathrm{~cm}$ in diameter) (Fig 3b). Close to this outcrop (Roseau river, right bank, Narakiel's Inn : location 5; Figs. 2b, 3b), an ash-and pumice-PDC deposit is covered by a $40 \mathrm{~cm}$ thick sequence of stratified ash-and pumicefallout beds, in which reworked volcanic material is intercalated; it is covered by a $30 \mathrm{~cm}$ thick lithic-rich Plinian fallout deposit. The top of the outcrop is made of reworked ash-and pumice-rich volcanic material. A small quarry, not totally vegetated, on the left bank of the Roseau River (Lacorne Quarry: location 7; Figs. 2b, 3b,) shows the superposition of a stratified Plinian fallout deposited on a strongly sloping basement $\left(20^{\circ} \mathrm{dip}\right)$, followed by an ash-and pumice-PDC deposit with abundant large pumice clasts and charcoals. The link road deposits (location 6; Figs. 2b, 3b) have been studied in details by Howe et al. (2014). Three pumiceous PDCs are intercalated with ash flows, paleosols and a single fallout deposit. In the upper part of the Roseau valley, highly welded ignimbritic deposits form cliffs 50 to $100 \mathrm{~m}$ high visible at Trafalgar falls (location 18; Figs. 2b, 4f). The deposits are prismed, highly indurated and pumices are highly flattened, generating fiammes.

\subsubsection{The Layou sections (location 8 , sea cliff; Figs. 2a, 3a, 4a,b)}

In the valley of Layou a thick sequence of ash-and pumice-PDC deposits is recognized in a large area including a sea cliff in continuity with a nearby large quarry. The sequence begins by a pumice-fallout deposit, $22 \mathrm{~cm}$ thick, massive, poorly sorted with small pumices, covering a paleosol developed on a thick pebble-rich conglomerate. It is covered by a $8 \mathrm{~cm}$ thick accretionary lapilli-rich ash fallout deposit. More than $40 \mathrm{~m}$ thick ash-and pumice-PDC deposits covers the fallout deposit. The thickness of each ash-and pumice-PDC deposits increases upward from few meters at the base to 10 meters at the top. The upper PDC are welded with prisms, but pumices are slightly to not flattened. Within the valley, large cliffs 
are visible in the landscape but not accessible for sampling. In the upper part of the Layou valley the ash-and pumice-PDC deposits outcrop along the road at Bells locality (location 9, Bells; Fig. 2a,).

\subsubsection{Grande Savane - Salisbury sections (location 10; Figs. 2a, 3a)}

The Grande Savane deposits, north of Layou, near Salisbury, form a large fan on the West coast. The pumiceous sequence covers a thick sequence of block-and ash-flow deposits in some place replaced by pebble-rich conglomerate. The sequence can be divided in two stratigraphic units. Unit 1 (hereafter referred as Grande Savane 1) is composed of a series of welded ash-and pumice-PDC deposits, rubefied for the first one. Unit 2 (hereafter referred as Grande Savane 2) is made of non-welded deposits covering the Unit 1 welded deposits without intercalated soil formation. Unit 2 is composed of a fallout deposit made of a succession of ash-and pumice-beds, covered by a few meters thick ash-and pumice-PDC deposit. The top of unit 2 is composed of a succession of reworked stratified deposits with rounded pumices and a muddy matrix.

\subsubsection{Grand Fond section (location 11; Figs. 2a, 3a, 4c)}

The Grand Fond pumiceous deposits cover a paleosol developed on a conglomerate. The sequence begins with a $70 \mathrm{~cm}$ thick stratified Plinian fallout deposit composed of a succession of fine- and coarse-grained beds. This pumice fallout deposit is covered by a $5 \mathrm{~m}$ thick ashand pumice-PDC deposit rich in large pumices (up to $40 \mathrm{~cm}$ in diameter), covered by a series of three surge deposits, all decimetric in thickness, ash- to sand-grained, normally graded, showing few laminations, and by a $2 \mathrm{~m}$ thick pumice PDC deposit containing very large pumices (up to $80 \mathrm{~cm})$. These first deposits are topped by a series of thick $(\sim 30 \mathrm{~m}$ in 
thickness) ash-and pumice-PDC deposits that can be followed in the valley. These deposits are not welded.

\subsubsection{Grand Bay section (location 12; Figs. 2a, 3c)}

In Berekua - Grand Bay, thick ash-and pumice-PDC deposits outcrop in a quarry near the sea. These deposits can be followed in the valley of Geneva where they form high cliffs in both sides of the valley. They are also present in a small quarry at Geneva Estate where they are covered by a block-and ash-flow deposit associated to a lava dome originating from the PPVC.

Hereafter, we detail three additional outcrops that we studied for comparison with the ignimbritic eruptions. At Fond St. Jean (location 13; Figs. 2a, 3c) along the south coast, a $1 \mathrm{~m}$ thick fallout deposit is covered by an ash-and pumice-PDC deposit forming a vertical cliff at the sea side. At Petite Savane, (location 14; Figs. 2a, 3c) a series of four weathered Plinian fallout deposits (PS1 to PS4) are composed of small pumice clasts (less than $4 \mathrm{~cm}$ in diameter); they are separated by thick mature paleosols. The upper two pumice fallout deposits are stratified. In the northwestern part of Dominica, north of Londonderry river near the Melville airport, (location 15; Fig. 2a), thick ash-and pumice-PDC deposits form a cliff at the sea side.

\section{2. ${ }^{14} C$ ages}

A series of charcoals and paleosols have been sampled in the different outcrops and quarries (see location in Figs. 2, 3). The results are reported in Table 1 and Fig. 5 (See also Table 1 in supplementary material). 
Two charcoals sampled in the Layou ash-and pumice-PDC deposits (location 8) give the oldest age, with an average age of $50598 \pm 5590 \mathrm{yr}$ cal BP (Table 1 and Supplementary material, Table 1). The large uncertainty on the age is due to the fact that the age is at the resolution limit of the ${ }^{14} \mathrm{C}$ dating method; a third charcoal gives a radiocarbon age older than 47800 yr BP. In the Roseau valley, the paleosol below the basal Plinian fallout deposit in the Cocoyer Estate quarry (location 1, Fig. 5a) and organic matter sampled within the first eruptive unit of the fallout deposit display similar age of $31061 \pm 307$ and $30512 \pm 512 \mathrm{yr}$ cal BP. Two charcoals sampled in the ash-and pumice-PDC deposits in the Goodwill quarry (location 2, Fig. 5a), show a mean age of $33413 \pm 690 \mathrm{yr}$ cal BP. Four charcoals sampled in the ash-and pumice-PDC in the Lacorne quarry (location 7, Fig. 5b) give a mean age of 32 $037 \pm 519 \mathrm{yr}$ cal BP. A unique age of $24046 \pm 357 \mathrm{yr}$ cal BP has been obtained for the Grand Fond pumiceous deposit (location 11) on a charcoal sampled in the first ash-and pumice-PDC deposit covering the Plinian fallout deposit. No age has been obtained on the last two ignimbritic deposits of Grande Savane and Grand Bay. A series of paleosol have been sampled at the base of different fallout deposits at the top of the Goodwill quarry (location 2), at the Goodwill entrance (location 5) and in the Petite Savane section (location 14). At Goodwill, the paleosols intercalated between the successive Plinian fallout deposits (PPR1 to 3) give ages of $12619 \pm 88,12513 \pm 129$ and $9391 \pm 94 \mathrm{yr}$ cal BP from the lower to the upper deposits. The paleosol at the base of Goodwill entrance fallout deposit (location 3) provides an age $18095 \pm 205 \mathrm{yr}$ cal BP. The two paleosols sampled at the base of two more recent fallout deposits at Petite Savane (location 14) have an age of $10377 \pm 124$ and $5360 \pm$ 39 yr cal BP.

\subsection{Lithology}


The lithology of 49 samples of Plinian fallout and PDC deposits can be used to distinguish different groups of deposits based on the proportion of crystals and particularly orthopyroxene, clinopyroxene and amphibole (Fig. 6; Table 2 for summary) the presence or absence of quartz and the abundance of accidental clasts (dominantly hydrothermally altered clasts). The comparison between the fallout and the pumiceous PDC deposits, when present within the same sequence, show that the Plinian fallout deposits display more homogeneous lithological characteristics than their PDC counterpart (with the PDC domain overlapping the Plinian one). This may be explained by the possible gravity segregation during transport within the flow (Calder et al., 2000) compared to the fallout. Nevertheless, where the fallout is absent, the data obtained on the PDC may serve to discriminate between the different deposits, keeping in mind possible data dispersion. Hereafter, the abundance of mineral phases is expressed with respect to the total crystal fraction.

The pumice fallout deposit from Layou (location 8) is different from the other pumiceous deposits by containing a significant proportion of amphibole (13\%; Table 2; Fig. 6a; Table 2 in supplementary material) and few quartz (1-2\%) - that are absent in the other deposits - but no or very few clinopyroxenes. The PDC deposit counterpart evidences similar proportion of amphibole as the fallout. The Plinian fallout deposit from Roseau (location 1) contains a lower proportion of amphibole than Layou ( 2\% with respect to 13\%), slightly higher clinopyroxene content, for similar proportion of orthopyroxene $(\sim 25 \%)$. The flow deposit counterpart shows a similar amphibole content but a more variable orthopyroxene/clinopyroxene ratio than the fallout. Grand Fond fallout deposit (location 11) contains no amphibole, but similar proportions of pyroxene (orthopyroxene and clinopyroxene) as Roseau. The flow deposit counterpart shows the same characteristics than the fallout. For Grande Savane (location 10), Grande Savane 1 has the same signature as 
Layou, with a high proportion of amphibole ( 10\%) but without quartz, whereas Grande Savane 2 shows completely different lithological proportions, with in particular no amphibole.

Within the Roseau valley numerous pumiceous deposits have been identified (location 3 to 7). The lithology evidences that the PPR3, the Link fall and the fallout deposit of the Roseau river right bank (Narakiel's inn) display similar signature (Fig. 6b). The others do not have amphibole and differ by the relative abundance of orthopyroxene with respect to clinopyroxene (Fig. 6b). The PPR1 fallout deposit sampled in the Goodwill quarry shows the highest proportion of orthopyroxene. The two fallout deposits of the Roseau river right bankroundabout and the associated flows show the same domain as the flow deposit of the Roseau river right bank (Narakiel's inn) and the Link flow 2. The PPR2 fallout deposit in the Goodwill quarry is correlated with the Ash flow 1 and 2 deposits of the Link road. The Goodwill entrance fallout deposit (location 3), though close to Goodwill quarry, has a different signature with a higher proportion of clinopyroxene; this is similar to the PDC deposits sampled in the left bank of Roseau river (location 7) and the bottom flow of the link road (location 6).

In the south of Dominica, we first focus on the Grand Bay ignimbrite (Fig. 6c), for which only PDC deposits can be identified, clearly on the beach but less easily along the different valleys. Three samples taken along the Geneva valley (Prinsteate Estate, Eris Estate and Geneva Estate; Fig. 6c) evidence the same signature as Grand Bay, with no amphibole and a orthopyroxene/clinopyroxene ratio similar to some deposits within the Roseau valley. The results obtained on five fallout deposits at Fond St. Jean and Petite Savane show either a composition close to those of Grand Bay (amphibole absent, PS1, PS3 and PS4) or amphibole-present (the Fond St. Jean - fallout and flow deposits and the Plinian fallout deposit of Petite Savane, PS2) (Fig. 6c). 


\subsection{Magma composition}

\subsubsection{Major elements}

All whole rocks of the major pumiceous eruptions are dacitic (Fig. 7a). Yet, the magmas of Layou, Grande Savane and Fond St-Jean are slightly more differentiated $\left(\mathrm{SiO}_{2}>64 \mathrm{wt} \%\right.$ for alkali content $\sim 5 \mathrm{wt} \%)$ than those of Roseau, Grand Fond, Grand $\mathrm{Bay}\left(\mathrm{SiO}_{2}: 62-63 \mathrm{wt} \%\right.$ for alkali content 4.5-5.5 wt\%) or Londonberry $\left(\mathrm{SiO}_{2}>61.5 \mathrm{wt} \%\right.$ for alkali content $\sim 4.5$ wt $\%$ ). All residual glasses are rhyolitic, with $\mathrm{SiO}_{2}$ between 76.5 and $78.0 \mathrm{wt} \%$ and alkali content between 5.5 and $7.0 \mathrm{wt} \%$. The Morne Trois Pitons and the Micotrin lava domes are also dacitic (Fig. 7a); no data has been obtained on Morne Diablotins lava domes.

\subsubsection{Trace element}

Selected trace element correlation diagrams are presented in order to characterize the geochemical signature of the different eruptions (Fig. 8). Whole rocks, residual glasses and separated minerals describe a perfect linear correlation through origine between $U$ and $T h$, both highly incompatible elements and used as a differentiation index. The results show that the correlation is similar for all studied deposits in Dominica. Such a positive U-Th correlation suggests that the whole rocks and the residual glasses are related by a fractional crystallization process (Fig. 8a, c). Sr generally behaves as a strong incompatible element ; but here the massive feldspar crystallization induces a compatible behaviour when plotting $\mathrm{Sr}$ as a function of $\mathrm{K}_{2} \mathrm{O}$ in whole rocks and residual glasses (Fig. 8c, d).

Other trace elements such as rare-earth elements (La, $\mathrm{Dy}, \mathrm{Yb}), \mathrm{Rb}$ or $\mathrm{Zr}$ are helpful to distinguish trends that may be used as a reference to correlate with other deposits (Fig. 9). In particular, $\mathrm{Yb}-\mathrm{La}, \mathrm{Rb}-\mathrm{Zr}$ or $\mathrm{Dy} / \mathrm{La}-\mathrm{SiO}_{2}$ correlations, using $\mathrm{La}$ and $\mathrm{Zr}$ as incompatible element tracer of differentiation process, such as $\mathrm{SiO}_{2}$, evidence two signatures : the Layou-Grande 
Savane 1 trend, already present in whole rocks but more precisely indentified using residual glasses, is dominated by the amphibole crystallization effect. Amphibole induces a Dy and Yb impoverishment of the residual glasses with respect to whole rocks (similar to Y, not shown; Figs. 9c, d, e). Although the differentiation feature is similar to Roseau, Grand Bay and Grand Fond, amphibole provides a particular signature of the Layou-Grande Savane 1 volcanic products. Unfortunately no systematic data has been obtained for Londonderry (only one whole rock). The three main crystals, orthopyroxene - feldspar - Fe-Ti oxide, are responsible for the signature of Roseau, Grand Bay and Grand Fond magmas. The volcanic products from the PPR and the southern part of Dominica (Fond St. Jean, Petite Savane) display geochemical signature which is similar in composition to the Roseau-Grand Fond-Grand Bay one. Least-square mass balance calculation based on trace element content provides estimates for crystallinity between 38 and $48 \%$ (Layou: $48 \%$; Roseau: $45 \%$; Grand Fond: $38 \%$; Grand Bay: $44 \%$ ). Relative errors are $<5 \%$ (Tables 3 to 7 in Supplementary Material).

\section{Discussion}

\subsection{Toward a new stratigraphy of the ignimbritic deposits of Dominica}

On the basis of the fieldwork (stratigraphy), ages (charcoals within volcanic deposits and paleosols), lithology and geochemical data (major and trace element signature on whole rock and residual glass), we propose a revised chronostratigraphy of the pumiceous deposits of the last tens of thousands years of Dominica allowing to unravel several unconstrained chronostratigraphic correlations. Here after we discuss the different eruptions on the basis of the proposed emission vents. 


\subsubsection{Morne Trois Pitons- Micotrin vent}

\subsubsection{Roseau eruption}

The mean age that we obtain for the Roseau deposits is $33342 \pm 382$ yr cal BP (Fig. 5; Table 1). Different ages were previously obtained for the deposits recognized in the Roseau valley ( 28 000 to $46000 \mathrm{yr}$ cal BP) by different authors (Howe et al., 2015a, 2015b, 2014; Lindsay et al., 2005b), but some of them belong to other eruptions. Surprisingly, most of the fallout and PDC deposits recognized in different sections at the bottom of the Roseau valley (Fig 2, locations 3-7) actually belong to more recent eruptions and were deposited in the valley dug by erosion after the Roseau event.

The lithological and geochemical characteristics of the Roseau deposits, together with the new ages provided here, allowed correlating and deciphering the genetic origin of several deposits that were originally attributed to the Roseau tuff eruption. The deposits of the Roseau eruption are typically characterized by a low proportion of amphibole $(\sim 2 \%)$ and clinopyroxene (2-3\%) compared to the high proportion of orthopyroxene (16-25\%); no quartz is present (Table 2; Table 2 in supplementary material). The rhyolitic melt of Roseau has a trace element signature weakly influenced by the crystallization of low proportion of amphibole and clinopyroxene (Fig. 9).

The distribution of the Roseau deposits argues for a vent localized on the summit area of Morne Trois Pitons-Micotrin volcanic center (Fig. 2). The two voluminous lava domes of Morne Trois Pitons in the north and Micotrin in the south occupy the summit area. The similarity in the geochemical signature between these lava domes and the Roseau pumiceous deposits are in agreement with a common magma origin (Fig. 8, 9). The large range of ${ }^{14} \mathrm{C}$ dates (between $28844 \pm 1983$ and $877 \pm 108$ yr cal BP (Lindsay et al., 2005b; Roobol et al., 1983; Wadge, 1989) recorded in different block-and ash-flow deposits associated to these two 
lava domes, underlines the long and complex lava dome growth history that follows the Roseau eruption.

\subsubsection{Grand Fond eruption}

The deposits that filled the valleys of Rosalie and Grand Fond on the eastern coast of the island show first a succession of various pumice fallout and surge deposits followed by a thick sequence of pumiceous PDC deposits. The sole age obtained on a charcoal at the base of the first PDC overlying the fallout deposit is of $24046 \pm 357 \mathrm{yr}$ cal BP, which is slightly younger than the previous ages between $30000 \pm 1220$ and $36800 \pm 8079 \mathrm{yr}$ cal BP (Carey and Sigurdsson, 1980). Taken into account the large uncertainty on these two ages and for comparison with the ages obtained in this study (by AMS), the age of $24046 \pm 357 \mathrm{yr}$ cal BP for Grand Fond eruption is preferred. This makes this eruption more recent than Layou and Roseau eruptions. The lithological data indicate a high proportion of orthopyroxene (23-26\%), few clinopyroxenes (3-5\%) but no amphibole and quartz, contrary to Roseau deposits that show some amphiboles and fewer clinopyroxenes. Based on their mineralogical and age differences, Grand Fond and Roseau may be considered as two separate eruptions, although following similar geochemical signatures. The Grand Fond deposits are located on the eastern flank of the Morne Trois Pitons-Micotrin volcanic center, which make it a probable eruptive center.

\subsubsection{Grand Bay eruption}

The outcrop conditions in the Grand Bay area precluded any identification of the base of the eruptive sequence: only thick ash-and pumice-PDC deposits are observed in the Geneva valley down to Grand Bay. Geochemically, Grand Bay shares a common signature with Grand Fond and Roseau eruptions. The lithology of the deposits, with presence of 
clinopyroxene (7\%) but no amphibole, is close to that of Grand Fond but clearly differs from those of Roseau. Different origins for Grand Bay eruption have been proposed. These deposits were originally related to the PPVC (Lindsay et al., 2003), with no correlation with the Roseau eruption contrary to a more recent work that considered them as part of the Roseau sequence based on whole rock geochemistry (Smith et al., 2013). Taking into account the UTh/He age proposed by Howe et al. (2014) of $62.6 \pm 4$ ka we can argue that Grand Bay is an event different from Grand Fond eruption. We assume that Grand Bay deposits originate from Morne Trois Pitons-Micotrin volcanic center, the upper part of the Geneva valley not allowing to follow clearly the cliffs due to the presence of younger lava domes (e.g. Watt Mountain or Morne Anglais dated to $<10000 \mathrm{yr}$ (Lindsay et al., 2005b).

\subsection{Morne Diablotins vent}

\subsubsection{Grande Savane eruption}

The related deposits that form the Grande Savane fan may be divided into two units with different lithological characteristics. The deposits of Grande Savane 1 are characterized by a high proportion of amphibole $(10 \%)$, but no clinopyroxene nor quartz. The non-welded deposits of Grande Savane 2 do not contain amphibole or quartz, but clinopyroxene (4\%), and higher proportion of orthopyroxene. They belong to two different eruptions. Considering the location and distribution of both deposits within the different valleys leading to the sea, they clearly originate from Morne Diablotins volcanic center. The unique age comes from the uppermost deposit of Grande Savane 2 and suggests a minimum age > $22000 \mathrm{yr}$ BP (Sparks et al., 1980). But considering the ages obtained for the Morne Diablotins lava dome products (Howe et al., 2015b; Smith et al., 2013), both Grande Savane events are probably significantly older than this minimum age of $22000 \mathrm{yr}$ BP. The geochemical signature of Grande Savane 1 is clearly different from the other pumiceous deposits: the Dy behavior highlights the 
“amphibole sponge" effect on magma composition as evidenced by (Davidson et al., 2007) (Fig. 9e).

\subsubsection{Layou}

The deposits that fill the Layou valley were first associated to the Roseau Tuff deposits (Carey and Sigurdsson, 1980), before becoming one independent ignimbritic eruption (Smith et al., 2013; Howe et al., 2014). The ${ }^{14} \mathrm{C}$ age of $50598 \pm 5530 \mathrm{yr}$ cal. BP we obtained on these samples is consistent, within dating method uncertainties, with those proposed by Howe et al. (2014). Lithologically, the Layou ignimbrite fingerprint is different from the others, with a significant proportion of amphibole (13\%), automorphic quartz (1-2\%; the sole deposit to show them), and no clinopyroxene. The geochemical trend of Layou magma follows the same as for Grande Savane 1 magma, mainly explained by the "amphibole sponge" effect, although the latter does not contain quartz and is slightly less differentiated. The lithological, geochemical and age evidences thus validate Layou as an event independent from Roseau.

The origin of the Layou deposits is controversal. On the field, they can be followed uphill the Layou valley up to the locality of Bells (location 9, Fig. 2). The upstream of Layou river results from the confluence of several rivers: mostly coming from the Morne Diablotins volcanic center but also from Morne Trois Pitons volcanic center. Unfortunately, the outcrop conditions in the upper part of the valleys preclude any clear identification of the origin of the Layou deposits. Yet, the geochemical signature of the magma (trace element correlation of the residual glasses), the lithological data (presence of amphibole) and the presence of amphibole in the lava dome clasts from Morne Diablotins (Howe et al., 2015a) suggest that the magmas at the origin of the Layou deposit share similar characteristics with those of Grande Savane 1. Thus we suggest that the vent at the origin of the Layou deposits is likely to be the Morne Diablotins volcanic center, as for the Grande Savane 1 event. 


\subsubsection{Other pumiceous (Plinian-type) eruptions}

\subsubsection{The post-Roseau Plinian events}

Several Plinian eruptions occurred after the Roseau eruption (Fig. 5c; Table 1). The first one, the deposits of which are located on the left bank of Roseau river (Lacorne quarry, location 7; Fig. 2), occurred probably soon after the Roseau eruption as indicated by the ages obtained on four charcoals sampled in the PDC deposit, giving a mean age of $32037 \pm 519 \mathrm{yr}$ cal BP (Fig. 5b). Whereas this age is close to the Roseau event one, the two deposits differ in terms of presence of amphibole (in the Roseau products but absent in this PDC deposit). The abundance of charcoals in the pumice PDC deposits indicates that the eruption occurred long time enough after the Roseau event so that the forest had time to grow again (even if it does not take more that few centuries in a humid tropical climate). This deposit belongs to the same eruptive event as the 'Link flow 1' deposit of the Link road (Location 6; Figs. 2b, 3b) as they present similar lithological characteristics.

The six following eruptions are younger, based on four ages obtained on different paleosols at the base of the Plinian deposits covering the Roseau eruption ones (i.e., Goodwill entrance: $18095 \pm 205$ yr cal BP, PPR1: $12619 \pm 88$ yr cal BP, PPR2 : $12513 \pm 129$ yr cal BP and PPR3: $9391 \pm 94$ yr cal BP; Fig. 5c) or stratigraphic arguments. Based on lithological similarities, the deposits identified at the Roseau river right bank - roundabout, the flow deposit of the Roseau river right bank - Narakiel's inn and the link flow 2 may be gathered and considering their stratigraphic position, they likely correspond to an eruptive event that occurred between the Roseau left bank and the Goodwill Entrance eruption, between $32037 \pm$ 519 and $18095 \pm 205 \mathrm{yr}$ cal BP. PPR1 represent a single event (Table 1). The PPR2 deposits may be correlated to the Ash flow 1 and 2 of the Link Road (location 6). Although the magma 
composition of all these deposits are similar (dacite whole rocks and rhyolitic residual glasses), there are some differences in terms of lithology with the presence of amphibole in the more recent deposits of PPR3 - Link fall - Right bank Narakiel's inn fallout and variations in the proportion of accidental clasts in the Plinian fallout deposits. No age has been obtained on the two Roseau right bank and Link fall Plinian deposits overlying the Roseau PDC, but these deposits are mineralogically close to PPR3. The latest event, the Link flow 3, is stratigraphically at the top of the Link road section and corresponds to an eruption that occurred after the link fall event (correlated to the PPR3 eruption). We dated this last event at $9391 \pm 94 \mathrm{yr}$ cal BP which is younger than the U-Th/He age of $25 \pm 2 \mathrm{ka}$ obtained by Howe et al. (2014). Therefore, these seven post-Roseau Plinian eruptions in the central part of Dominica correspond to distinct events which significantly modifies the previous interpretations. Interestingly, these Plinian fallouts were not followed by voluminous PDCs, as occurred during the previous large ignimbritic events. Taking into account the thickness of the pumice fallout deposits and the presence of the ash-and pumice-PDCs in the valley of Roseau, we can consider that all these Plinian eruptions originate from a close vent, probably from Morne Trois Pitons-Micotrin volcanic center, as for the Roseau eruption.

\subsubsection{2. $\quad$ Fond St. Jean - Petite Savane}

Several Plinian fallout deposits crop out at Fond St. Jean and Petite Savane (locations 13, 14; Fig. 2, 3) on the south-eastern part of Dominica. Four distinct fallout deposits separated by paleosols are present at Petite Savane (location 14). The two latest Plinian eruptions, PS3 and PS4, are dated through their related paleosols and give ages of $10377 \pm 124$ and $5360 \pm$ 39 yr cal BP, respectively. Mineralogically they cannot be correlated to Fond St. Jean or Grand Bay deposits. They more likely correspond to an explosive activity that occurs during the recent period, possibly originated from vents such as Morne Anglais, Watt Mountain or 
Grande Soufrière Hill's (Fig. 2a). Nevertheless ${ }^{14} \mathrm{C}$ dates of Fond St. Jean deposits provide ages of $41012 \pm 939 \mathrm{yr}$ cal BP (Lindsay et al., 2005b), making it an older event, distinct from Grand Bay on the basis of mineralogy (amphibole present in Fond St. Jean whereas absent in Grand Bay). Fond St. Jean and PS2 have similar lithological characteristics, and could belong to the same event.

On the basis of these new data, we can consider five voluminous ignimbritic deposits and 12 to 13 smaller Plinian eruptions occurring in the last tens of thousands years in the central part of Dominica. All these eruptions contributed to disperse ash-and pumice-fallout deposits offshore and turbiditic deposits (coming from large ash-and pumice-PDCs entering the sea) in the Grenada Basin. They contribute to the voluminous offshore deposits proposed previously to belong to a unique and large eruption (Carey and Sigurdsson, 1980; Whitham, 1989).

\subsection{Erupted volume : characteristics of the deposits and estimates}

\subsubsection{Thickness ratio of Plinian fallout and PDC deposits}

A Plinian eruption is classically defined by a first highly sustained eruptive column at the origin of significant fallout deposit, followed by partial up to total column collapse. This results in commonly thick Plinian fallout deposits overlain by successive non-welded ash-and pumice-PDC deposits of low volumes. On the contrary, the ignimbritic eruptions in Dominica evidence small volumes of fallout deposits overlain by thick ash-and pumice-PDC deposits. To account for such a reverse ratio of Plinian fallout over PDC deposit thicknesses, one must invoke an eruptive dynamic of rapid magma overflow from the vent, after a small Plinian phase. This is highlighted by the partly welded deposits in the proximal zones which indicate 
a high temperature of emplacement that cannot be reached by repetitive collapse of high Plinian columns (Walker, 1983). In details, the thickness of the Grand Fond basal fallout deposit $(70 \mathrm{~cm})$ is greater than those of Layou $(30 \mathrm{~cm})$ and Roseau $(26 \mathrm{~cm})$, for similar deposit distances from the emission vent of $\sim 7-8 \mathrm{~km}$. For Roseau eruption, however, a $\sim 15$ cm Plinian fallout deposit is intercalated within the first Roseau PDC deposits, increasing the total thickness of fallout deposit. But this difference on the basal fallout deposit thicknesses between the three ignimbritic eruptions may be better explained by the geographical position of the studied sections rather than a variation in the intensity of the beginning of the eruption, as the fallout dispersion in the Lesser Antilles is strongly dependent on the dominant wind in the high atmosphere. Indeed, for Layou and Roseau, the section thickness is measured on the leeward coast, whereas on the windward coast for Grand Fond. This influence on tephra dispersal is also evidenced in offshore fallout deposits, being thicker to the East (Carey and Sigurdsson, 1980). Other Plinian eruptions such as PPR1 or 2, involving lower total volume of magma, show a significantly higher thickness of fallout deposits, with more than $1 \mathrm{~m}$ at the same distance on the leeward coast, and comparatively lower volumes of ash-and pumicePDC deposits.

\subsubsection{Estimation of the emitted volumes}

The precise volume of emitted magma in Dominica is very difficult to estimate because of i) the poor outcrop conditions on the island due to the dense rainforest and ii) the likely loss of PDC material into the sea, as highlighted by some piston cores (Carey and Sigurdsson, 1980; Witham, 1989). As for the on-land deposits, the attribution of the offshore deposits to a given ignimbritic episode is questioned. The pyroclastic material in the Grenada Basin was first supposed to belong to the unique event of the Roseau Tuff, but the following studies have shown that not only the Roseau eruption extended offshore in the Grenada Basin, but nearly 
all the ignimbritic eruptions of Dominica, such as the Grande Savane one (Sparks et al., 1980). Recent lithological and geochemical investigations on cores obtained west of Martinique in the Grenada Basin during the IODP Expedition 340 also showed very thick $(\sim 110 \mathrm{~m})$ sequence of pumiceous turbiditic deposits originating from Dominica (Le Friant et al., 2015). All these deposits belong to eruptions that covered at least the last tens of thousands years. Based on a series of piston cores, Carey and Sigurdsson (1980) and Witham (1989) reckoned the turbiditic deposits to be $30 \mathrm{~km}^{3}$ in volume. These values originally given for a unique event, the Roseau Tuff eruption, must now be revised in the light of the recent stratigraphic constraints (i.e., several explosive events during the last $100000 \mathrm{yr}$ ). As a consequence, the volume of the on-land deposits per ignimbritic eruption is probably in the order of 1-3 $\mathrm{km}^{3}$ for the ash-and pumice-PDC deposits, 2-4 $\mathrm{km}^{3}$ for the pumice fallout deposits (on-land and offshore) and probably a minimum of 3-6 $\mathrm{km}^{3}$ for the offshore deposits (turbiditic deposits). A crude estimation of the total volume of the deposit for each ignimbritic eruption is in the order of $6-10 \mathrm{~km}^{3}\left(\sim 2.5-4 \mathrm{~km}^{3} \mathrm{DRE}\right)$ whereas probably lower for the more recent Plinian events $\left(\leq 1 \mathrm{~km}^{3}\right.$ DRE).

\section{4. $\quad$ Summit lava domes and possible caldera(s)}

The summit area of Morne Trois Pitons-Micotrin and Morne Diablotins volcanic centers is characterized by voluminous lava domes. The Morne Trois Pitons lava dome represents a very large volume of $2 \mathrm{~km}^{3}$ and shows a complex lobe morphology that may result of either one long eruption or several eruptions. The Micotrin lava dome, located on the southern flank of Morne Trois Pitons, is less voluminous. Both lava domes have compositions similar to the Roseau and Grand Fond pumiceous deposits and may have grown from a degassed magma at the end of these eruptions or more recently since some block-and ash-flow deposits at the base 
of these lava domes give much younger ages of $\sim 28843 \pm 1983$ to $877 \pm 108 \mathrm{yr}$ cal BP (Roobol et al., 1983, Lindsay et al., 2005b).

One striking field observation related to these eruptions is the absence of a large structure of caldera in the summit area of Morne Trois Pitons-Micotrin or Morne Diablotins. Some authors have mentioned the presence of caldera rims in the summit area of Morne Trois Pitons-Micotrin (Demange et al., 1985), but the structure has not been confirmed. South of Micotrin lava dome a scarp is present on a distance of $2 \mathrm{~km}$ with a convexity to the East (Fig. 10) but this structure cannot represent the rim of a caldera as no equivalent is observed to the West. The hydrographic system shows a radial distribution to the North, East and South of Morne Trois Pitons-Micotrin whereas to the West, the hydrographic system has an East-West direction from a curvilinear line including the identified scarp (Fig. 10). It may represent the limit of a horseshoe-shaped structure open to the Carribbean Sea. Voluminous offshore blocky debris avalanche deposits have been identified on the submarine western flank of the southwestern part of Dominica ( Le Friant et al., 2002; Boudon et al., 2007). They were attributed to the Soufrière horseshoe-shaped structure of PPVC, but the volume of this blocky debris avalanche deposit with megablocks visible in the bathymetry up to $2 \mathrm{~km}$ long and several hundred of meters high is too large in comparison of the volume of Soufrière horseshoe-shaped structure. A part of these debris avalanche deposits may originate from this possible horseshoe-shaped structure of Morne Trois Pitons-Micotrin. In comparison, on Morne Diablotins (Supplementary material, Fig. 1), the hydrographic system has a radial distribution from the summit and no structure (neither caldera nor horseshoe-shaped structure) is observed.

The absence of caldera associated with large-volume ignimbrite (in the order of $6-10 \mathrm{~km}^{3}$ of products, equivalent to $2.5-4 \mathrm{~km}^{3} \mathrm{DRE}$ ) is not common. Based on our recent experimental investigations, we propose an explanation related to the depth of the magma chambers below 
Dominica. Indeed, we estimate a magma storage depth of around 16-20 km (400-500 MPa ; Solaro et al., in revision), which could play as a limiting factor for collapse-caldera formation after reservoir emptying. Indeed, deep and small (low lateral extension) magma reservoirs tend to produce incoherent collapse with no peripheral faults and less effect at the surface (Geyer et al., 2006; Marti et al., 2008; Roche et al., 2000). Possible small structures, however, could be filled at the end of the eruptions or during more recent eruptions by the voluminous lava domes observed in the summit area, thus hiding them.

5.5. The large volumes of erupted magma in Dominica: an anomaly in the Lesser Antilles arc.

The existence of 4-5 eruptions producing a large volume of magma $\left(2.5-4 \mathrm{~km}^{3}\right.$ DRE/eruption) in the last tens of thousands years is an anomaly in the Lesser Antilles arc compared to the volume of magma emitted on the other islands. At Montagne Pelée, in Martinique, the eruptions are frequent (more than 28 eruptions were identified in the last 15 ky (Westercamp and Traineau, 1983, Boudon et al., 2013), but the volume of emitted magma for each eruption is low $\left(<0.3 \mathrm{~km}^{3}\right.$ DRE for the Plinian and lava dome-forming eruptions (Carazzo et al., 2012; Tanguy, 2004b) and we have no evidence of large volume of deposits in the past. At Soufrière of Guadeloupe, the last large eruption occurred 42000 years ago (Pintade eruption, Boudon et al., 1989) and produced an estimated volume of 2-3 $\mathrm{km}^{3}$ of products $\left(<1 \mathrm{~km}^{3} \mathrm{DRE}\right)$, which is still a lower volume than the eruptions of the central part of Dominica ( 2.5-4 $\mathrm{km}^{3}$ DRE). The less recurrent but voluminous ignimbritic eruptions punctuating the last tens of thousands years of volcanic activity of central Dominica may reflect a combination between locally higher magma production rate, possibly enhanced by a particular extensive tectonic context, and favorable conditions for magma accumulation and 
evolution over long timescales. The former consideration would imply a local flare-up condition effective only in the central part of Dominica (so excluding Morne aux Diables and the PPVC system and the neighboring islands of the arc). Several tectonic and structural studies have recognized a change in the arc subduction geometry (Macdonald et al., 2000; Wadge and Shepherd, 1984) and a particular segmentation of the arc making the local component of convergence normal to the front maximum in the central segment of the arc and decreasing away ( 35 km/Ma) (Mccann and Sykes, 1984; Wadge, 1986). Feuillet et al. (2010) recognized a complex fault system cutting the Caribbean plate in different directions. Two specific systems of active faults are identified: (i) NE-SW oriented normal-oblique faults creating trench parallel extension and arc-perpendicular half-grabens that disrupt the fore-arc reef platforms of Guadeloupe, Antigua-Barbuda and St. Martins - St. Barthelemy (Feuillet et al., 2002) and (ii) a fault set arranged in a right-stepping, en echelon array that follows the inner edge of the arc and accommodates a transtensional motion along the arc between Saba and Martinique. The Roseau Fault in Dominica is part of this second fault set (Bazin et al., 2010; Feuillet et al., 2011). Between Dominica and St. Lucia, the stress regime changes with deformation that seems to be more diffuse and accommodated by smaller faults or fissures. All together, these structural and tectonic particularities may create an extensive regime and flare-up conditions fostering the lateral expansion of reservoirs and subsequent accumulation of large magma volumes under Dominica.

In addition, the deep storage conditions of Dominica magma (16-20 km; Solaro et al., in revision) contrasting with the shallow crustal reservoirs frequently drained to eruption (6-7 km depth) typically evidenced for the magmas of Montagne Pelée (Martel et al., 1998), Soufrière de Guadeloupe (Poussineau, 2005), and Soufrière Hills of Montserrat (Barclay et al., 1998), may lead to longer magma accumulation timescales in reservoirs fed by lowmedium inflow rates. Inflow rates exceeding the rate of cooling (to preserve magma 
mobility), but comparable to the timescales of viscous relaxation of the reservoir walls (to prevent eruption), represent favorable conditions for large magma volumes accumulation (Degruyter et al., 2016). Thus higher magma production rate is not a necessary condition for the larger magma volumes characterizing the central part of the island. Rather, the absence of crustal reservoirs frequently erupting may favor longer timescales of magma accumulation and differentiation in larger and deeper magma reservoirs.

\section{Conclusion}

This study proposes a revised chronostratigraphy for the pumiceous eruptions that occur in the last tens of thousands years in Dominica in light of a combined chronological, lithological and geochemical investigation. We emphasize the importance of glass chemistry together with whole rock data in order to accurately correlate outcrops. We recognized five major ignimbritic eruptions involving several $\mathrm{km}^{3}$ DRE, namely Grande Savane 1 and Layou eruptions that we infer coming from Morne Diablotins volcanic center and Roseau, Grand Fond and Grand Bay eruptions that we infer coming from Morne Trois Pitons-Micotrin volcanic center. The absence of identified calderas may result from deep magma storage. By correlations of the different outcrops, we emphasize that several pumiceous deposits located in the Roseau valley represent distinct Plinian eruptions, whose youngest one occurred within the last 5 ky. Potential explosive activity in Dominica have crucial implications in terms of volcanic risk mitigation in case of reactivation not only at the island scale but also for the Caribbean area, due to both fallout product dispersion and possible arrival of large amounts of pyroclastic material into the sea with related tsunami hazard. 


\section{Acknowledgements}

The authors began this work to a first financial support from IPGP before benefiting from INSU-Aléas support (2013). M. Fialin, N. Rividi are acknowledged for EPMA analyses, A. Michel and P. Bürckel for geochemical analyses and S. Hidalgo for sample preparations. J.-P. Dumoulin (LSCE) and the LMC14 team is acknowledged for ${ }^{14} \mathrm{C}$ dates. Parts of this work were supported by IPGP multidisciplinary program PARI, and by Paris-IdF region SESAME Grant no. 12015908. We are very grateful to J.M. Lindsay and two anonymous reviewers for their constructive reviews. IPGP contribution $\mathrm{N}^{\circ} \mathrm{xx}$.

\section{References}

1. Balcone-Boissard, H., Villemant, B., Boudon, G., Michel, A., 2008. Non-volatile vs volatile behaviours of halogens during the AD 79 plinian eruption of Mt. Vesuvius, Italy. Earth Planet. Sci. Lett. 269, 66-79. doi:10.1016/j.eps1.2008.02.003

2. Barclay, J., Rutherford, M.J., Carroll, M.R., Murphy, M.D., Devine, J.D., Gardner, J., Sparks, R.S.J., 1998. Experimental phase equilibria constraints on pre-eruptive storage conditions of the Soufriere Hills magma. Geophys. Res. Lett. 25, 3437-3440. doi:10.1029/98GL00856

3. Bazin, S., Feuillet, N., Duclos, C., Crawford, W., Nercessian, A., Bengoubou-Valérius, M., Beauducel, F., Singh, S.C., 2010. The 2004-2005 Les Saintes (French West Indies) seismic aftershock sequence observed with ocean bottom seismometers. Tectonophysics 489, 91-103. doi:http://dx.doi.org/10.1016/j.tecto.2010.04.005

4. Bond, A., Sparks, R.S.J., 1976. The Minoan eruption of Santorini, Greece. J. Geol. Soc. London. 132, 1-16. doi:10.1144/gsjgs.132.1.0001

5. Boudon, G., Le Friant, A., Komorowski, J.-C., Deplus, C., Semet, M.P., 2007. Volcano flank instability in the Lesser Antilles Arc: Diversity of scale, processes, and temporal recurrence. J. Geophys. Res. Solid Earth 112, n/a-n/a. doi:10.1029/2006JB004674 
6. Boudon, G., Semet, M.P., Vincent, P.M., 1989. The Evolution of La Grande Découverte (La Soufrière) Volcano, Guadeloupe (F.W.I.), in: Latter, J.H. (Ed.), Volcanic Hazards:

Assessment and Monitoring. Springer Berlin Heidelberg, Berlin, Heidelberg, pp. 86-109. doi:10.1007/978-3-642-73759-6_5

7. Boudon, G., Villemant, B., Le Friant, A., Paterne, M., Cortijo, E., 2013. Role of large flankcollapse events on magma evolution of volcanoes. Insights from the Lesser Antilles Arc. J. Volcanol. Geotherm. Res. 263, 224-237.

8. Bronk Ramsey, C., 2009. Bayesian Analysis of Radiocarbon Dates. Radiocarbon 51, 337-360. doi:10.2458/azu_js_rc.v51i1.3494

9. Carazzo, G., Tait, S., Kaminski, E., Gardner, J.E., 2012. The recent Plinian explosive activity of Mt. Pelée volcano (Lesser Antilles): The P1 AD 1300 eruption. Bull. Volcanol. 74, $2187-$ 2203. doi:10.1007/s00445-012-0655-4

10. Carey, S.N., Sigurdsson, H., 1980. The roseau ash: Deep-sea tephra deposits from a major eruption on Dominica, lesser antilles arc. J. Volcanol. Geotherm. Res. 7, 67-86. doi:10.1016/0377-0273(80)90020-7

11. Carignan, J., Hild, P., Mevelle, G., Morel, J., Yeghicheyan, D., 2001. Routine Analyses of Trace Elements in Geological Samples using Flow Injection and Low Pressure On-Line Liquid Chromatography Coupled to ICP-MS: A Study of Geochemical Reference Materials BR, DR-N, UB-N, AN-G and GH. Geostand. Newsl. 25, 187-198. doi:10.1111/j.1751908X.2001.tb00595.x

12. Davidson, J., Turner, S., Handley, H., Macpherson, C., Dosseto, A., 2007. Amphibole 'sponge' in arc crust? Geology 35, 787 LP-790.

13. Degruyter, W., Huber, C., Bachmann, O., Cooper, K.M., Kent, A.J.R., 2016. Magma reservoir response to transient recharge events: The case of Santorini volcano (Greece). Geology 44, 23-26. doi:10.1130/G37333.1

14. Demange, J., Leborne, H., Traineau, H., Westercamp, D., 1985. Histoire volcano- structurale de la Region sud de la Dominique: Wotten-Waven, Soufrière, premiers résultats, in: Bureau de Recherches Geologiques et Minieres, Institut Mixte de Recherches Geothermiques, R. 85 S. 
068 I.-G. (Ed.), . p. 114.

15. Feuillet, N., Beauducel, F., Tapponnier, P., 2011. Tectonic context of moderate to large historical earthquakes in the Lesser Antilles and mechanical coupling with volcanoes. J. Geophys. Res. Solid Earth 116. doi:10.1029/2011JB008443

16. Feuillet, N., Leclerc, F., Tapponnier, P., Beauducel, F., Boudon, G., Le Friant, A., Deplus, C., Lebrun, J.-F., Nercessian, A., Saurel, J.-M., Clément, V., 2010. Active faulting induced by slip partitioning in Montserrat and link with volcanic activity: New insights from the 2009 GWADASEIS marine cruise data. Geophys. Res. Lett. 37, n/a--n/a. doi:10.1029/2010GL042556

17. Feuillet, N., Manighetti, I., Tapponnier, P., Jacques, E., 2002. Arc parallel extension and localization of volcanic complexes in Guadeloupe, Lesser Antilles. J. Geophys. Res. 107, 2331. doi:10.1029/2001JB000308

18. Fournier, N., Witham, F., Moreau-Fournier, M., Bardou, L., 2009. Boiling lake of dominica, west indies: High-temperature volcanic crater lake dynamics. J. Geophys. Res. Solid Earth 114. doi:10.1029/2008JB005773

19. Geyer, A., Folch, A., Martí, J., 2006. Relationship between caldera collapse and magma chamber withdrawal: An experimental approach. J. Volcanol. Geotherm. Res. 157, 375-386. doi:http://dx.doi.org/10.1016/j.jvolgeores.2006.05.001

20. Gurenko, A.A., Trumbull, R.B., Thomas, R., Lindsay, J.M., 2005. A melt inclusion record of volatiles, trace elements and $\mathrm{Li}-\mathrm{B}$ isotope variations in a single magma system from the Plat Pays Volcanic Complex, Dominica, lesser antilles. J. Petrol. 46, 2495-2526. doi:10.1093/petrology/egi063

21. Halama, R., Boudon, G., Villemant, B., Joron, J.L., Le Friant, A., Komorowski, J.C., 2006. Pre-eruptive crystallization conditions of mafic and silicic magmas at the Plat Pays volcanic complex, Dominica (Lesser Antilles). J. Volcanol. Geotherm. Res. 153, 200-220. doi:10.1016/j.jvolgeores.2005.12.001

22. Howe, T.M., Lindsay, J.M., Shane, P., 2015a. Evolution of young andesitic-dacitic magmatic systems beneath Dominica, Lesser Antilles. J. Volcanol. Geotherm. Res. 297, 69-88. 
doi:10.1016/j.jvolgeores.2015.02.009

23. Howe, T.M., Lindsay, J.M., Shane, P., Schmitt, A.K., Stockli, D.F., 2014. Re-evaluation of the Roseau Tuff eruptive sequence and other Ignimbrites in Dominica, Lesser Antilles 29, 531-546. doi:10.1002/jqs.2723

24. Howe, T.M., Schmitt, A.K., Lindsay, J.M., Shane, P., Stockli, D.F., 2015b. Time scales of intra-oceanic arc magmatism from combined U-Th and (U-Th)/He zircon geochronology of Dominica, Lesser Antilles. Geochemistry, Geophys. Geosystems 16, 347-365. doi:10.1002/2014GC005636

25. Jochum, K.P., Weis, U., Schwager, B., Stoll, B., Wilson, S.A., Haug, G.H., Andreae, M.O., Enzweiler, J., 2016. Reference Values Following ISO Guidelines for Frequently Requested Rock Reference Materials. Geostand. Geoanalytical Res. 40, 333-350. doi:10.1111/j.1751908X.2015.00392.X

26. Johnston, E.N., Sparks, R.S.J., Phillips, J.C., Carey, S., 2014. Revised estimates for the volume of the Late Bronze Age Minoan eruption, Santorini, Greece. J. Geol. Soc. London. 171, 583-590. doi:10.1144/jgs2013-113

27. Lavigne, F., Degeai, J.-P., Komorowski, J.-C., Guillet, S., Robert, V., Lahitte, P., Oppenheimer, C., Stoffel, M., Vidal, C.M., Surono, Pratomo, I., Wassmer, P., Hajdas, I., Hadmoko, D.S., de Belizal, E., 2013. Source of the great A.D. 1257 mystery eruption unveiled, Samalas volcano, Rinjani Volcanic Complex, Indonesia. Proc. Natl. Acad. Sci. 110, 16742-16747. doi:10.1073/pnas.1307520110

28. Le Friant, A., Boudon, G., Komorowski, J.C., Deplus, C., 2002. L'île de la Dominique, à l'origine des avalanches de débris les plus volumineuses de l'arc des Petites Antilles. Comptes Rendus Geosci. 334, 235-243. doi:10.1016/S1631-0713(02)01742-X

29. Legendre, Y., 2012. Reconstruction fine de l'histoire éruptive et scénarii éruptifs à la Soufrière de Guadeloupe : vers un modèle intégré de fonctionnement du volcan. IPGP - Université Paris Diderot thesis.

30. Lindsay, J.M., Robertson, R.E.A., Shepherd, J.B., Ali, S., 2005a. Volcanic Hazard Atlas of the Lesser Antilles. Seismic Research Unit, the University of West Indies, Trinidad and Tobago, 
W.I.

31. Lindsay, J.M., Smith, A.L., Roobol, M.J., Stasiuk, M. V, 2005b. Dominica, in: Lindsay, J.M., Robertson, R.E.A. , Shepherd, J.B., Ali, S. (Eds.), Volcanic Hazard Atlas of the Lesser Antilles. Seismic Research Unit, the University of West Indies, Trinidad and Tobago, W.I., pp. $1-48$.

32. Lindsay, J.M., Stasiuk, M., Shepherd, J.B., 2003. Geological history and potential hazards of the late-Pleistocene to Recent Plat Pays volcanic complex, Dominica, Lesser Antilles. Bull. Volcanol. 65, 201-220. doi:10.1007/s00445-002-0253-y

33. Lindsay, J.M., Trumbull, R.B., Siebel, W., 2005c. Geochemistry and petrogenesis of late Pleistocene to Recent volcanism in Southern Dominica, Lesser Antilles. J. Volcanol. Geotherm. Res. 148, 253-294. doi:10.1016/j.jvolgeores.2005.04.018

34. Lindsay, J.M., Trumbull, R.B., Siebel, W.,. Geochemistry and petrogenesis of late Pleistocene to Recent volcanism in Southern Dominica, Lesser Antilles. J. Volcanol. Geotherm. Res. 148, 253-294. doi:10.1016/j.jvolgeores.2005.04.018

35. Macdonald, R., Hawkesworth, C.J., Heath, E., 2000. The Lesser Antilles volcanic chain: A study in arc magmatism. Earth Sci. Rev. 49, 1-76. doi:10.1016/S0012-8252(99)00069-0

36. Martel, C., Pichavant, M., Bourdier, J.L., Traineau, H., Holtz, F., Scaillet, B., 1998. Magma storage conditions and control of eruption regime in silicic volcanoes: experimental evidence from Mt. Pelée. Earth Planet. Sci. Lett. 156, 89-99. doi:10.1016/S0012-821X(98)00003-X

37. Marti, J., Geyer, A., Folch, A., Gottsmann, J.H., 2008. Experimental, numerical and geophysical modelling of collapse calderas: a review, in: Gottsmann, J., Marti, J. (Eds.), Caldera Volcanism: Analysis, Modelling and Response. Amsterdam:Elsevier, pp. 233-284.

38. Mccann, W.R., Sykes, L.R., 1984. Subduction of aseismic ridges beneath the Caribbean Plate: Implications for the tectonics and seismic potential of the Northeastern Caribbean. J. Geophys. Res. 89, 4493-4519. doi:10.1029/JB091iB01p00787

39. Reimer, P., 2013. Selection and Treatment of Data for Radiocarbon Calibration: An Update to the International Calibration (IntCal) Criteria. Radiocarbon 55, 1923-1945. doi:10.2458/azu_js_rc.55.16955 
40. Roche, O., Druitt, T.H., Merle, O., 2000. Experimental study of caldera formation. J. Geophys. Res. Solid Earth 105, 395-416. doi:10.1029/1999JB900298

41. Roobol, M.J., Wright, J. V., Smith, A.L., 1983. Calderas or gravity-slide structures in the Lesser Antilles island arc? J. Volcanol. Geotherm. Res. 19, 121-134. doi:10.1016/03770273(83)90128-2

42. Self, S., Rampino, M.R., Newton, M.S., Wolff, J.A., 1984. Volcanological study of the great Tambora eruption of 1815. Geology 12, 659-663. doi:10.1130/00917613(1984)12<659:VSOTGT>2.0.CO;2

43. Self, S., Zhao, J.-X., Holasek, R.E., Torres, R.C., King, A.J., 1993. The Atmospheric Impact of the 1991 Mount Pinatubo Eruption, in: Fire and Mud: Eruptions and Lahars of Mount Pinatubo, Philippines. pp. 1089-1115.

44. Sigurdsson, H., 1972. Partly-welded pyroclast flow deposits in Dominica, Lesser Antilles. Bull. Volcanol. 36, 148-163. doi:10.1007/BF02596987

45. Sigurdsson, H., Carey, S., Alexandri, M., Vougioukalakis, G., Croff, K., Roman, C., Sakellariou, D., Anagnostou, C., Rousakis, G., Ioakim, C., Goguo, A., Ballas, D., Misaridis, T., Nomikou, P., 2006. Marine investigations of Greece's Santorini Volcanic Field. Eos, Trans. Am. Geophys. Union 87, 337. doi:10.1029/2006EO340001

46. Smith, A.L., Roobol, M.J., Mattioli, G.S., Fryxell, J.E., Daly, G.E., Fernandez, L.A., 2013. The Volcanic Geology of the Mid-Arc Island of Dominica, Lesser Antilles-The Surface Expression of an Island-Arc Batholith, Geological Society of America Special Papers. doi:10.1130/2013.2496

47. Smith, W.H.F., Sandwell, D.T., 1997. Global Sea Floor Topography from Satellite Altimetry and Ship Depth Soundings. Science (80-. ). 277, 1956 LP-1962.

48. Sparks, R.S.J., Sigurdsson, H., Carey, S.N., 1980. The entrance of pyroclastic flows into the sea I. oceanographic and geologic evidence from dominica, lesser antilles. J. Volcanol. Geotherm. Res. 7, 87-96. doi:10.1016/0377-0273(80)90021-9

49. Tanguy, J.-C., 2004a. Rapid dome growth at Montagne Pel\{é\}e during the early stages of the 1902--1905 eruption: a reconstruction from Lacroix’s data. Bull. Volcanol. 66, 615-621. 
doi:10.1007/s00445-004-0344-z

50. Tanguy, J.-C., 2004b. Rapid dome growth at Montagne Pelée during the early stages of the 1902-1905 eruption: a reconstruction from Lacroix’s data. Bull. Volcanol. 66, 615-621.

51. Vidal, C.M., Métrich, N., Komorowski, J.-C., Pratomo, I., Michel, A., Kartadinata, N., Robert, V., Lavigne, F., 2016. The 1257 Samalas eruption (Lombok, Indonesia): the single greatest stratospheric gas release of the Common Era. Sci. Rep. 6, 34868.

52. Wadge, G., 1989. A preliminary analysis of volcanic hazards in Dominica: Unpublished report,. Available from Seism. Res. Unit, Trinidad Tobago, Univ. West Indies 20.

53. Wadge, G., 1986. The dykes and structural setting of the volcanic front in the Lesser Antilles island arc. Bull. Volcanol. 48, 349-372. doi:10.1007/BF01074466

54. Wadge, G., 1985. Morne Patates volcano, southern Dominica, Lesser Antilles. Geol. Mag. 122, 253-260. doi:10.1017/S0016756800031460

55. Wadge, G., 1984. Comparison of volcanic production rates and subduction rates in the Lesser Antilles and Central America. Geology 12, 555-558. doi:10.1130/00917613(1984)12<555:COVPRA $>2.0 . \mathrm{CO} ; 2$

56. Wadge, G., Herd, R., Ryan, G., Calder, E.S., Komorowski, J.C., 2010. Lava production at Soufrière Hills Volcano, Montserrat: 1995-2009. Geophys. Res. Lett. 37. doi:10.1029/2009GL041466

57. Wadge, G., Shepherd, J.B., 1984. Segmentation of the Lesser Antilles subduction zone. Earth Planet. Sci. Lett. 71, 297-304. doi:10.1016/0012-821X(84)90094-3

58. Ward, G.K., Wilson, S.R., 1978. Procedures for Comparing and Combining Radiocarbon Age Determinations: a Critique. Archaeometry 20, 19-31. doi:10.1111/j.14754754.1978.tb00208.x

59. Westercamp, D., Traineau, H., 1983. The past 5,000 years of volcanic activity at Mt. Pelee martinique (F.W.I.): Implications for assessment of volcanic hazards. J. Volcanol. Geotherm. Res. 17, 159-185. doi:10.1016/0377-0273(83)90066-5

60. Whitham, A.G., 1989. The behaviour of subaerially produced pyroclastic flows in a subaqueous environment: Evidence from the Roseau eruption, Dominica, West Indies. Mar. 


\section{Figures}

Fig. 1. The Lesser Antilles arc. Predicted bathymetry is from Smith and Sandwell (1997). Contour interval $2000 \mathrm{~m}$ isolines is in bold. Volcanic islands are black, and subaerial coral reef platforms are dark gray. The $100 \mathrm{~m}$ depth submarine shelf is light grey. Dominica SRTM topographic radar map is highlighted (Courtesy of Dr. Ian C.F.Stewart).

Fig. 2. Schematic map of the ignimbritic deposits and sampling location. (A)- Dominica main ignimbrites highlighted in color from sea up to the valley, with the four main volcanic centers of Morne aux Diables, Morne Diablotins, Morne Trois Pitons - Micotrin and Plat Pays Volcanic Complex. The numbers refer to the outcrop locations. Sampling comprises the lava dome of Morne Trois Pitons (16, 15 $23^{\prime} 21^{\prime}$ 'N, $61^{\circ} 18^{\prime} 44^{\prime \prime} \mathrm{W}$; quarry on the northern side), and the lava dome of Micotrin $\left(17,15^{\circ} 20^{\prime} 08^{\prime}\right.$ ' $\mathrm{N}, 61^{\circ} 18^{\prime} 55^{\prime \prime} \mathrm{W}$; block and ash flow deposit near Freshwater lake for Micotrin). (B)- Detail of the outcrop locations within the Roseau valley. (1) Cocoyer Estate quarry, (2) Goodwill quarry, (3) Goodwill entrance, (4) Roseau right bank - roundabout, (5) Roseau right bank - Narakiel's inn, (6) Link road, and (7) Roseau left bank - Lacorne quarry. Pinkish domain: main fallout and PDC pumiceous deposits.

Fig. 3. Sections of the main Dominica ignimbrites. (A)- Layou, Roseau, Grand Fond and Grande Savane. (B)- The "Roseau valley" sections, with Goodwill, Goodwill entrance, Roseau right bank (roundabout and Narakiel's inn), Link road and Roseau left bank, as referenced in Fig. 2b. (C)- Grand Bay and laterally pumiceous deposits of Fond St. Jean and Petite Savane. Numbers refers to the locations as in Fig. 2 and ${ }^{14} \mathrm{C}$ ages are given in cal yr BP 
(Table 1 for details). The asterisk is for the newly described outcrops; the others have been revisited, as for example Layou for which a new locality has been described (Bells).

Fig. 4. Photos of the three main ignimbrites studied here: Layou, Roseau and Grand Fond. (A) Layou basal fallout deposit covered by a pyroclastic density current (PDC); (B) Layou partially welded pumiceous PDC; (C) Grand Fond PDC; (D) Roseau outcrop at Cocoyer quarry showing a basal Plinian fallout deposit (the white cleaned section on the outcrop) overlain by PDC deposits; (E) Roseau basal pumice fallout (white part) and the first PDC; (F) Roseau, welded PDC with fiammes at Trafalgar.

Fig. 5. Probability domain of calibrated ages (in cal BC) for (A) Roseau deposits (B) Roseau river left bank and (C) for Dominica. (A) Roseau deposits include the paleosol, the fallout and the pumiceous PDC deposits. (B) The four ages obtained for the left bank (quarry on the left bank of the Roseau river; location 7) come from charcoals that likely correspond to a "young" forest grown after the Roseau eruption. (C) Synthesis of the different ages obtained for Dominica: Layou, Roseau and Grand Fond. 'Goodwill entrance' is the fallout and pumiceous PDC deposit close to Goodwill quarry (location 3). PPR1 to 3 are the three fallout deposits at the top of the Goodwill quarry (location 2). PS1 and 2 are the fallout deposit at Petite Savane in the southeast of Dominica (location 14). Data are in Table 1 in supplementary material. Combined ages are noted with an asterisk $(*)$.

Fig. 6. Lithology of the pumiceous deposits shown in a orthopyroxene (OPx) - clinopyroxene (CPx) - amphibole (Amph) content ternary. Solid symbols: fallout deposit samples. Open symbols: PDC deposit samples associated to the fallout deposit; blue circles for Layou, blue diamonds for Grande Savane, red circles for Roseau, green circles for Grand Fond, yellow circles for Grand Bay. (A) The five ignimbritic deposits of Grande Savane 1 and 2, Layou, Roseau, Grand Fond and Grand Bay. (B) Details of the Roseau valley deposits. All the 
outcrops located in the Roseau valley, as shown in Fig. 2, are detailed here. (C) South Dominica: the Grand Bay ignimbritic deposit is compared to the other identified Plinian and pumiceous PDC deposits in the southern Dominica (Fond St. Jean and Petite Savane). Data are in Table 2 in supplementary material.

Fig. 7. Alkali-silica diagram for whole rocks (solid symbols) and residual glasses (open symbols). (A) the ignimbritic deposits of Layou, Roseau, Grand Fond, Grand Bay and Grande Savane (Fig. 2). (B) the other studied deposits: the different outcrops in the Roseau valley (locations 3, 4, 5, 7), the post-Roseau Plinian eruptions (PPR1 to 3, location 2), the Londonderry ignimbritic deposit (location 15), the Fond St. Jean Plinian deposit (location 13) and the two lava domes of Morne Trois Pitons and Micotrin. Analytical uncertainty on wholerock and residual glass $\mathrm{SiO}_{2}:<1 \%$ and alkalis : $<5 \%$; for the residual glasses, each point represents a mean value of at least 5 EMP analysis (Camparis, France). Data are in Table 3 and 4 in supplementary material.

Fig. 8. Petrology of the eruptive products on the basis of $\mathrm{U} / \mathrm{Th}$ and $\mathrm{Sr} / \mathrm{K}_{2} \mathrm{O}$ correlations for whole rocks (solid symbols) and residual glasses (open symbols). (A, B) the ignimbritic deposits of Layou, Roseau, Grand Fond, Grand Bay, Grand Savane (Fig. 2), and the main minerals (feldspars, orthopyroxenes, clinopyroxenes, amphiboles and oxides). (C, D) the different outcrops in the Roseau valley referred as 'Roseau related' including the deposits of the locations 2 (PPR1 to 3), 3 (Goodwill quarry), 4 (Roseau Right bank - Roundabout), 5 (Roseau right bank - Narakiel's inn) and 7 (Roseau left bank), the Londonderry ignimbritic deposit, the Fond St. Jean and Petite Savane Plinian deposits (referred as DOM Sud) and also the two lava domes of Morne Trois Pitons and Micotrin. For each diagram the degree of melt differentiation increases from left to right. Data are obtained by ICP-QMS on handpicked glass shards for residual glasses, powdered whole rocks and handpicked minerals. Data are in Table 5 to 7 in supplementary material. 
Fig. 9. Trace element signature on the basis of $\mathrm{Rb} / \mathrm{Zr}, \mathrm{Yb} / \mathrm{La}$ and $\mathrm{Dy} / \mathrm{Yb}$ vs. $\mathrm{SiO}_{2}$ correlations for whole rocks (solid symbols) and residual glasses (open symbols). Legend is as in Fig. 8. Data are in Table 5 to 7 in supplementary material.

Fig. 10. Timeline of the pumiceous eruptions of Dominica during the last $70000 \mathrm{yr}$. The age of each eruption is indicated. Boxes: pink: ignimbritic deposits; red: plinian fallout deposits; yellow: low volume PDC deposits. Eruption name: blue: eruptions from Morne Diablotins; black: eruptions from Morne Trois Pitons-Micotrin; orange: eruptions from the small volcanic centers south of Morne Trois Pitons. The two horizontal arrows indicate the time period of activity of Morne Diablotins and Morne trois Pitons-Micotrin lava domes.

Fig. 11. The hydrographic system of the central part of Dominica. The Morne Trois Pitons and Morne Micotrin lava domes are represented. The full black line indicates the scarp south of Morne Micotrin. The black dotted line corresponds to the limit of a possible large horseshoe structure open towards the Caribbean Sea, the black arrows indicating the direction of the flank collapse. The red dotted line indicates the south limit of a hypothetic caldera proposed by previous authors. The white arrows show the direction of the hydrographic system in the North, East and South part of the volcano.

Table 1: Synthesis of chronostratigraphic data and correlations between the different eruptions. Locations are precised and correspond to Fig. 1. Radiocarbon ages and calendar age conversions. Calibration uses the OxCal 4.2 program (Bronk Ramsey, 2009) and atmospheric data of the IntCal13 calibration curve (Reimer, 2013). The combined ages are radiocarbon ages (See Table 1 in Supplementary material for single ages). The calendar BP age is calculated on the basis of the range of cal $\mathrm{BC}$ ages obtained through OxCal, assuming a Gaussian repartition of the probability of age occurrence. The age with an asterisk is from literature. The lithological assembly is given together with the whole rock and glass 
composition. The trace elment particular signature in trace element is provided. The correlation established on the basis of chronostratigraphical, lithological and geochemical arguments are summarized.

Table 2. Lithological signature of the Layou, Roseau, Grand Fond, Grande Savane and Grand Bay ignimbritic deposits. Numbers are calculated crystal fraction percentages. 


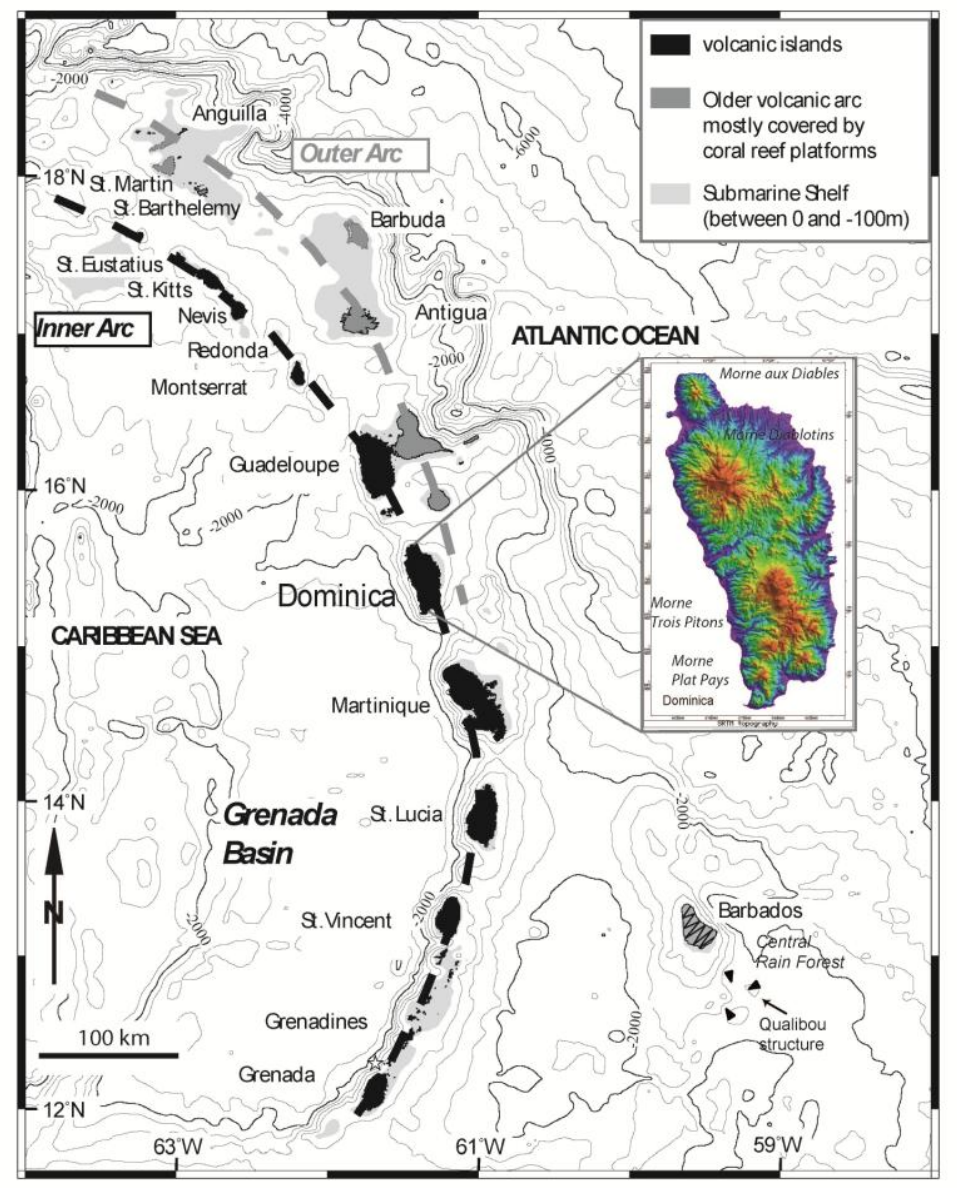

Figure 1 

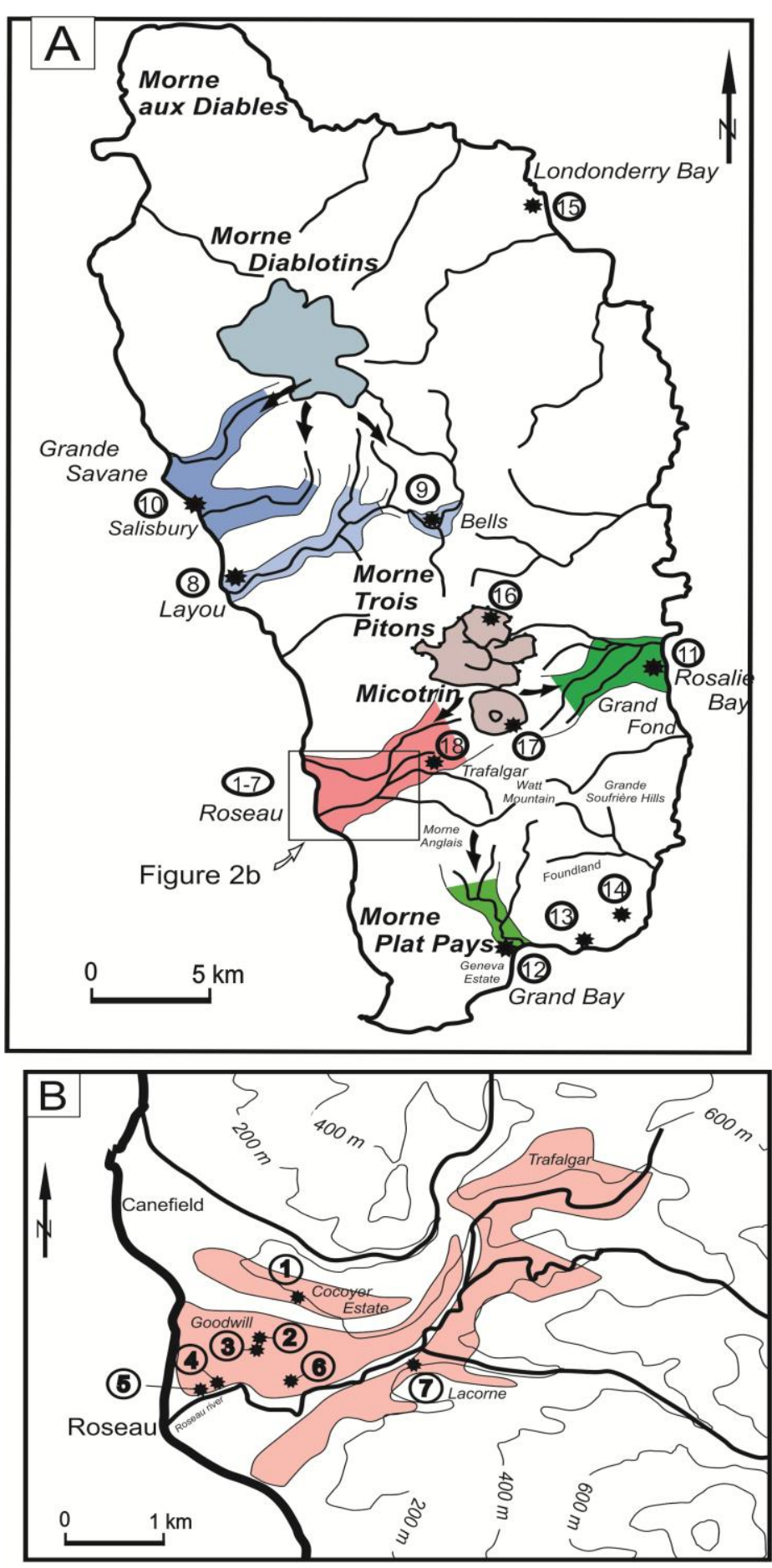

Figure 2 


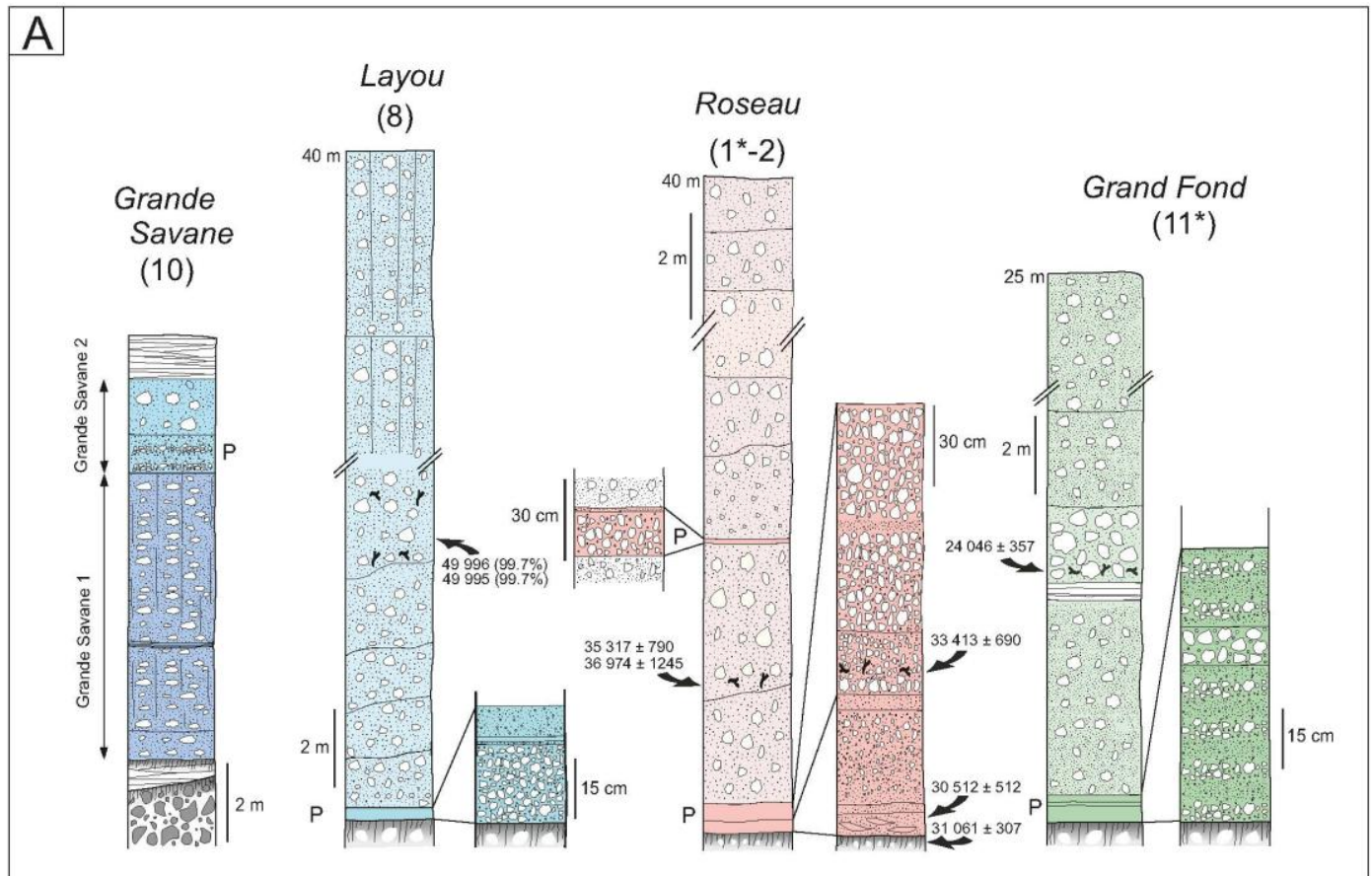

Figure 3a 


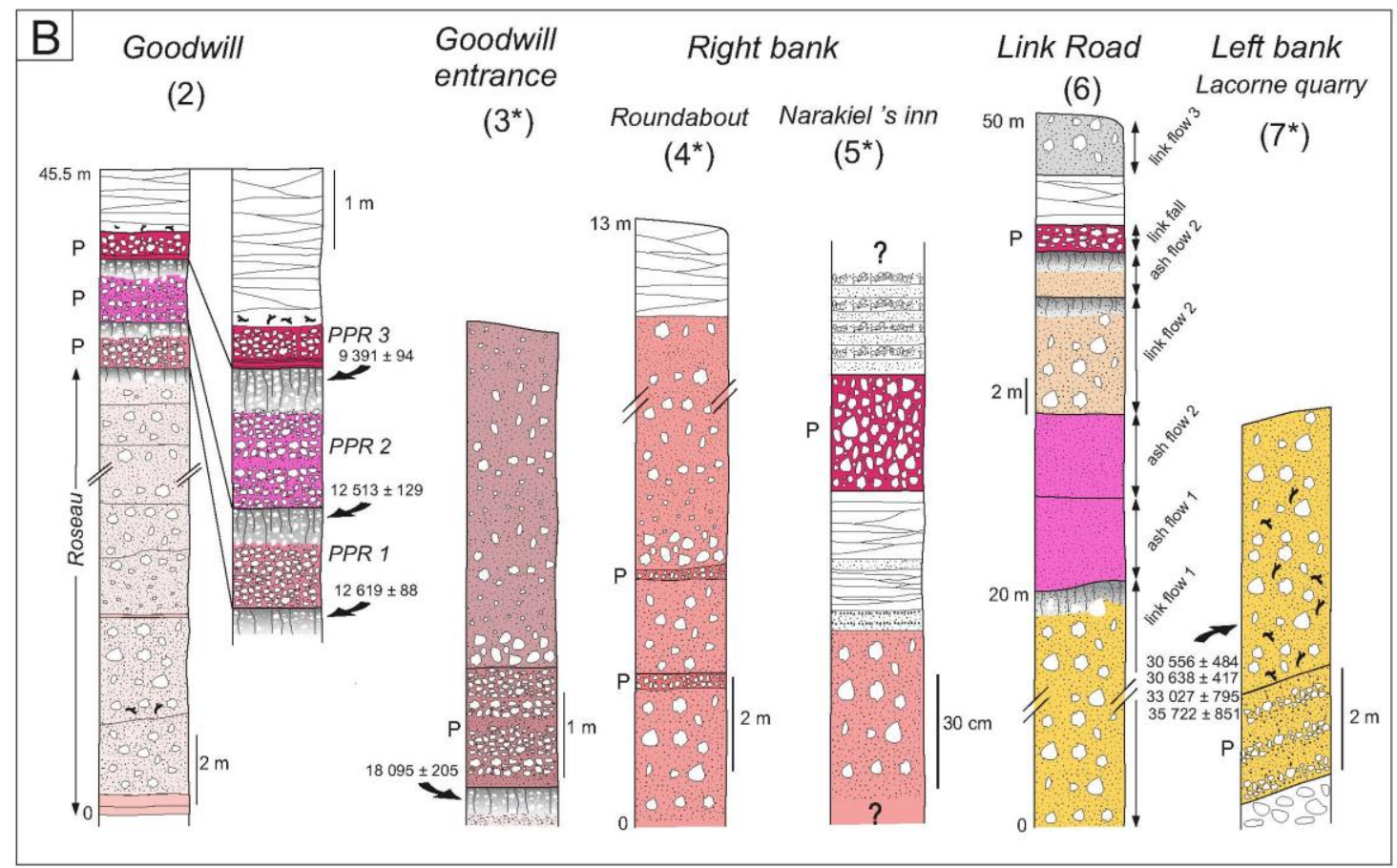

Figure $3 b$ 


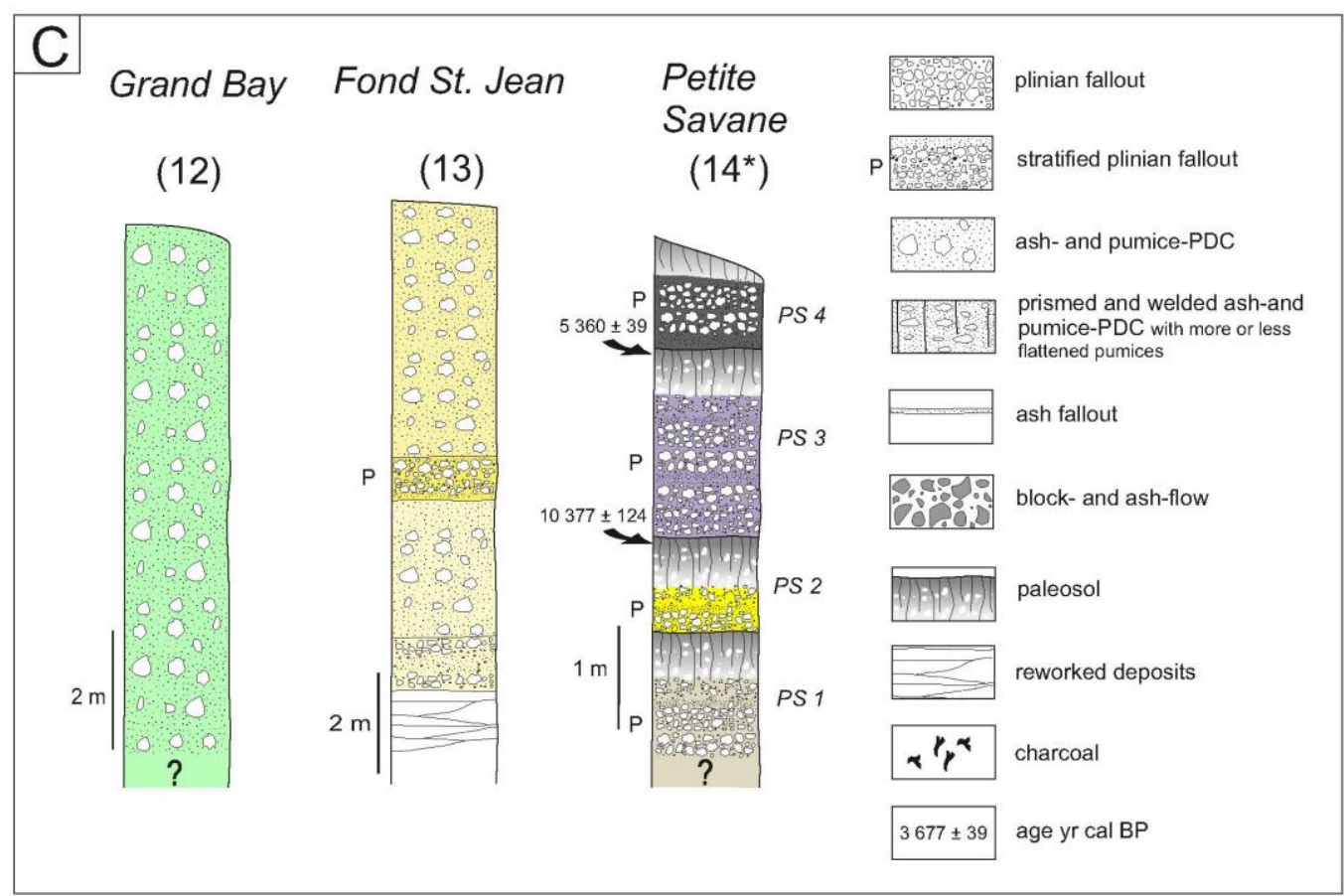

Figure 3c 

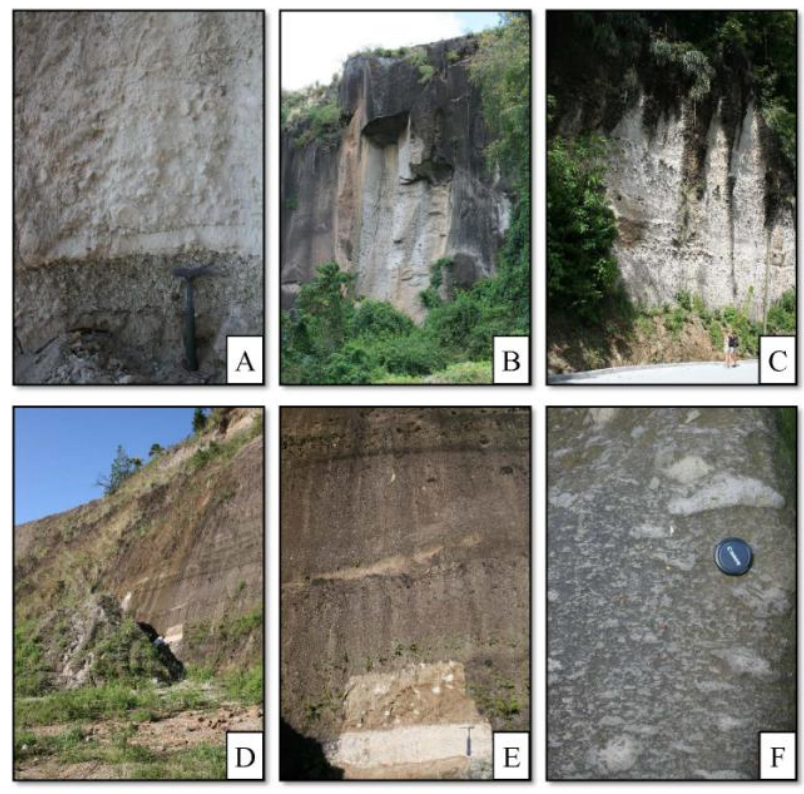

Figure 4

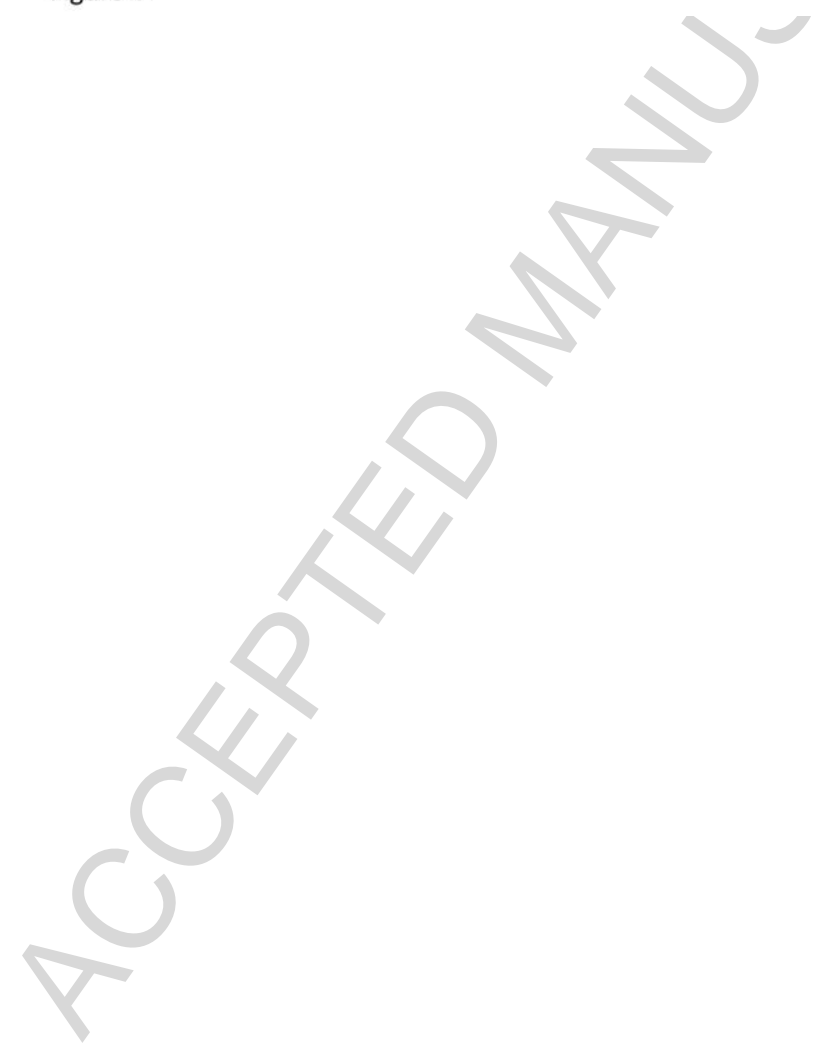




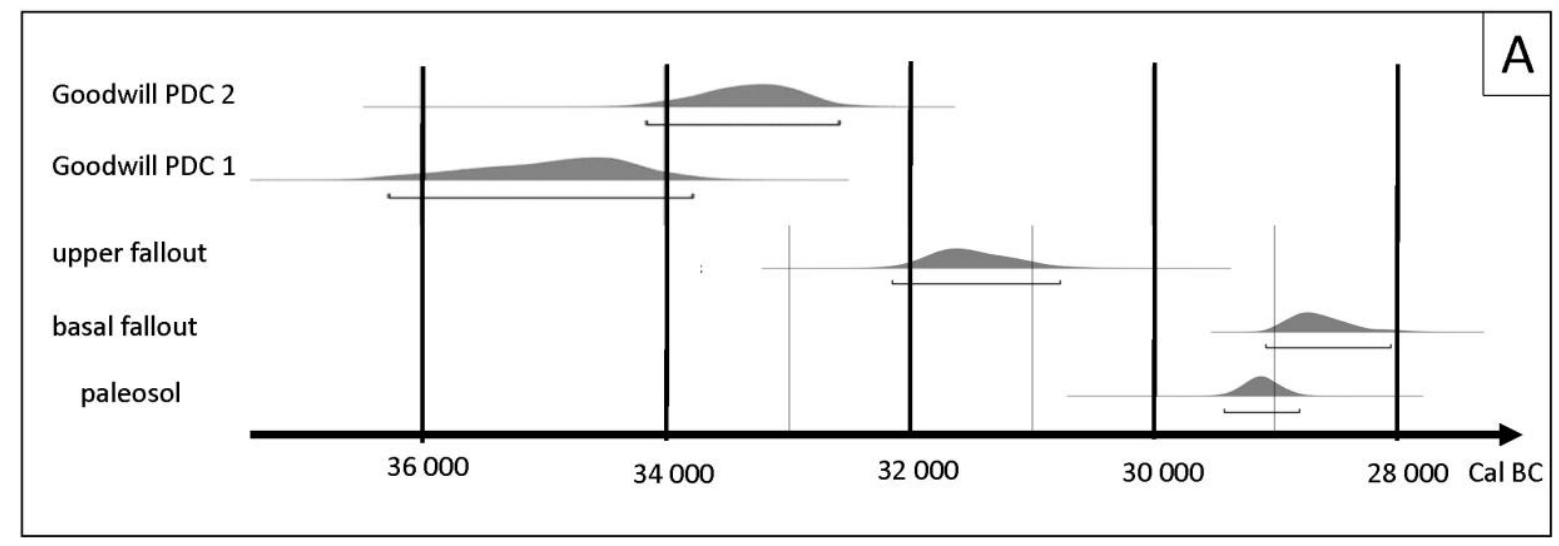

Figure 5 


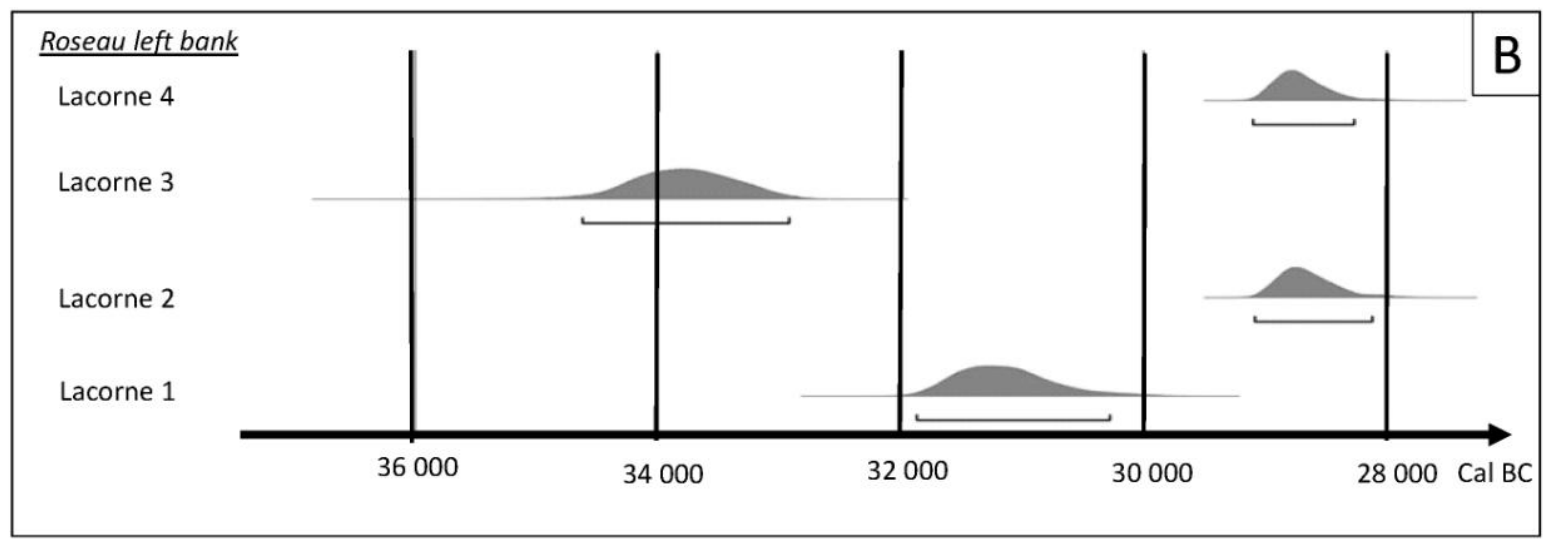

Figure 5 


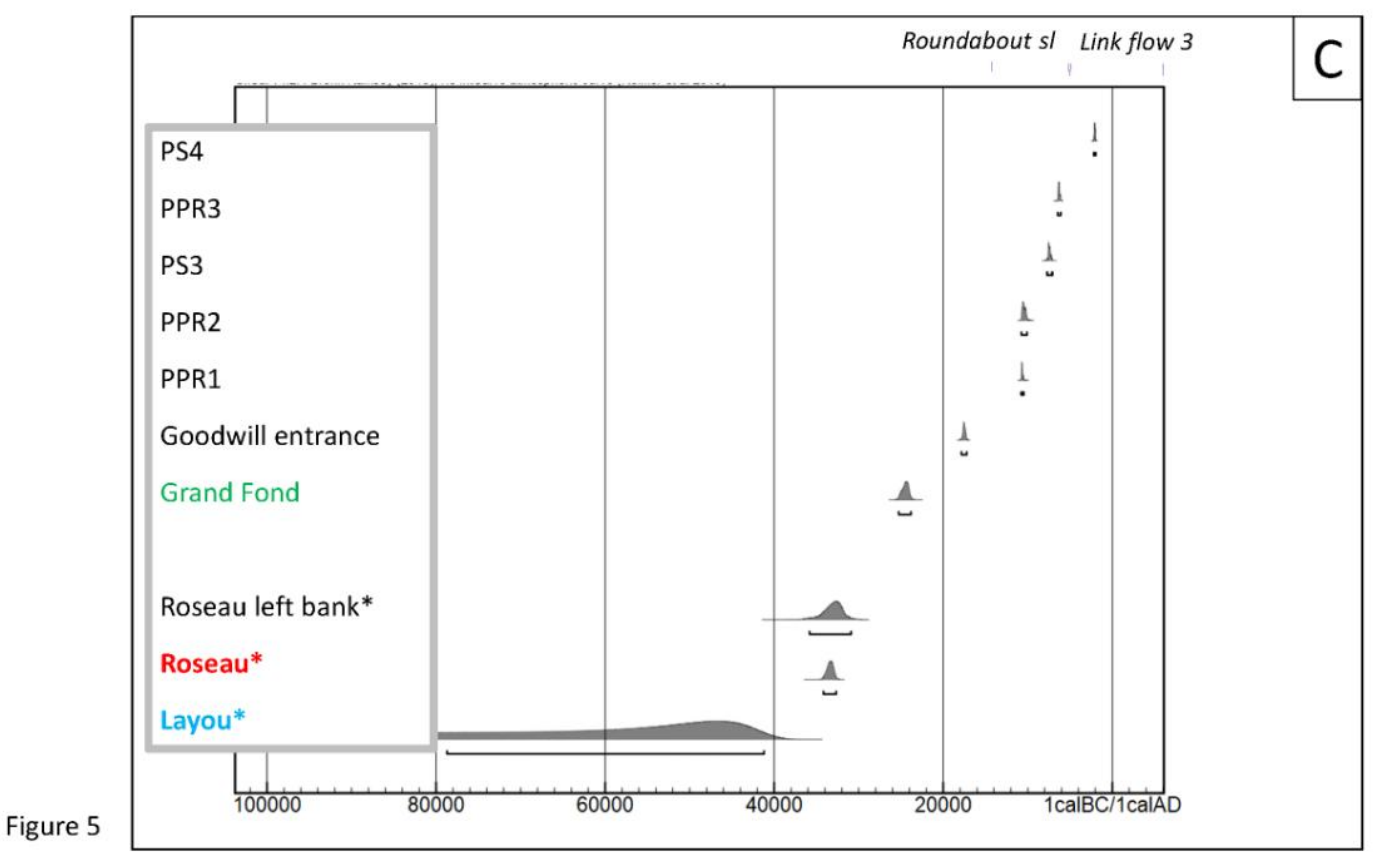




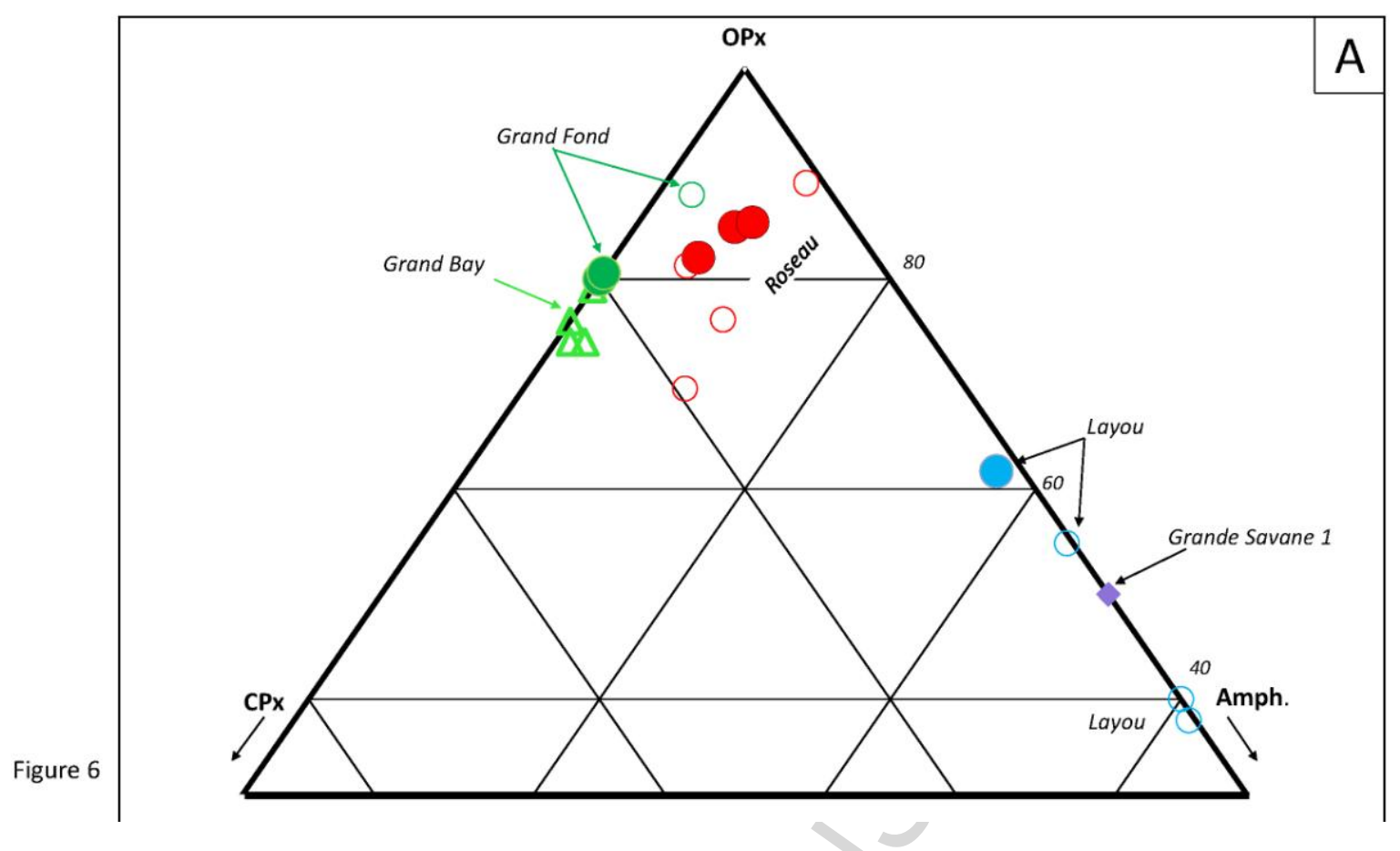




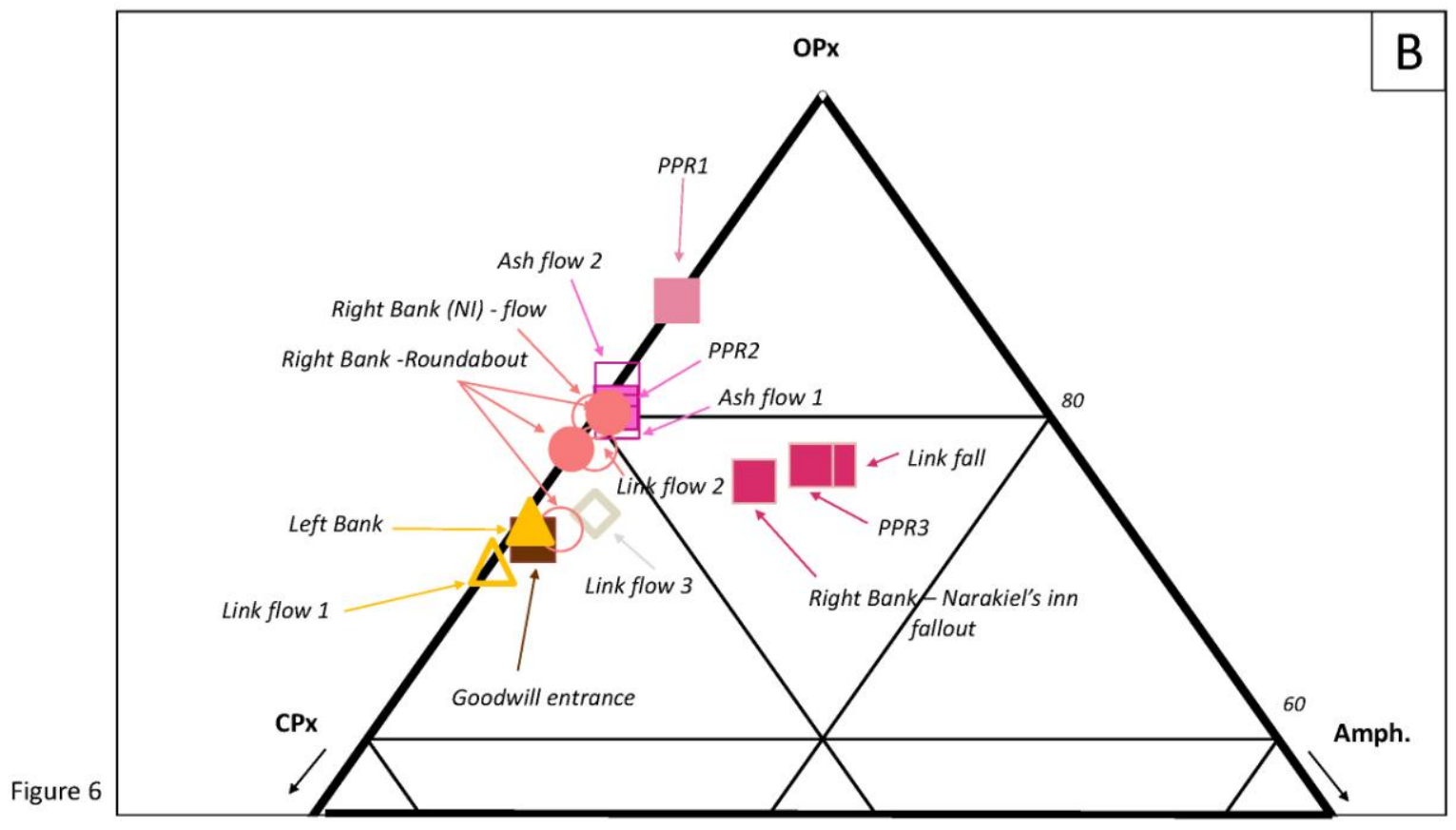




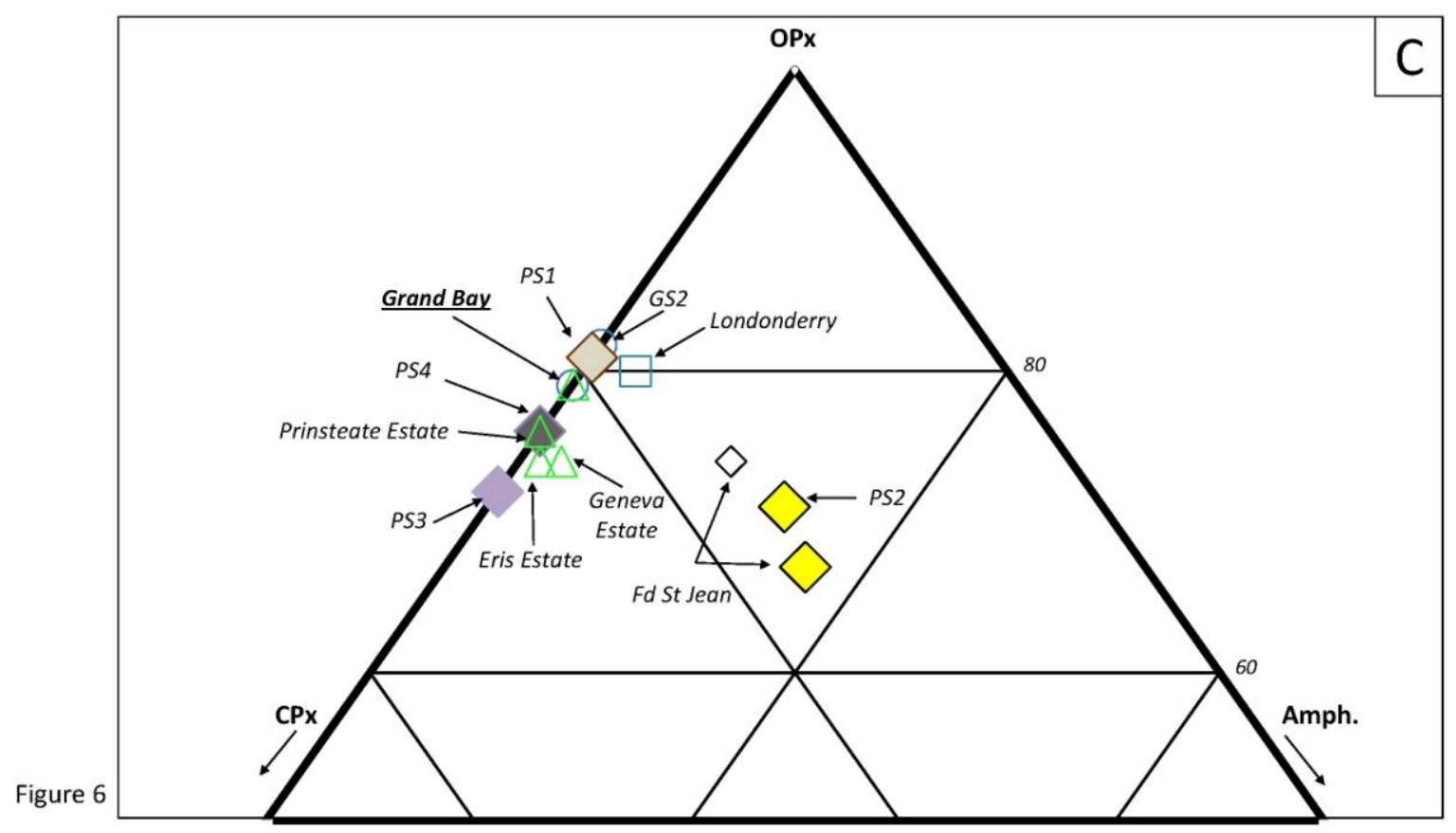



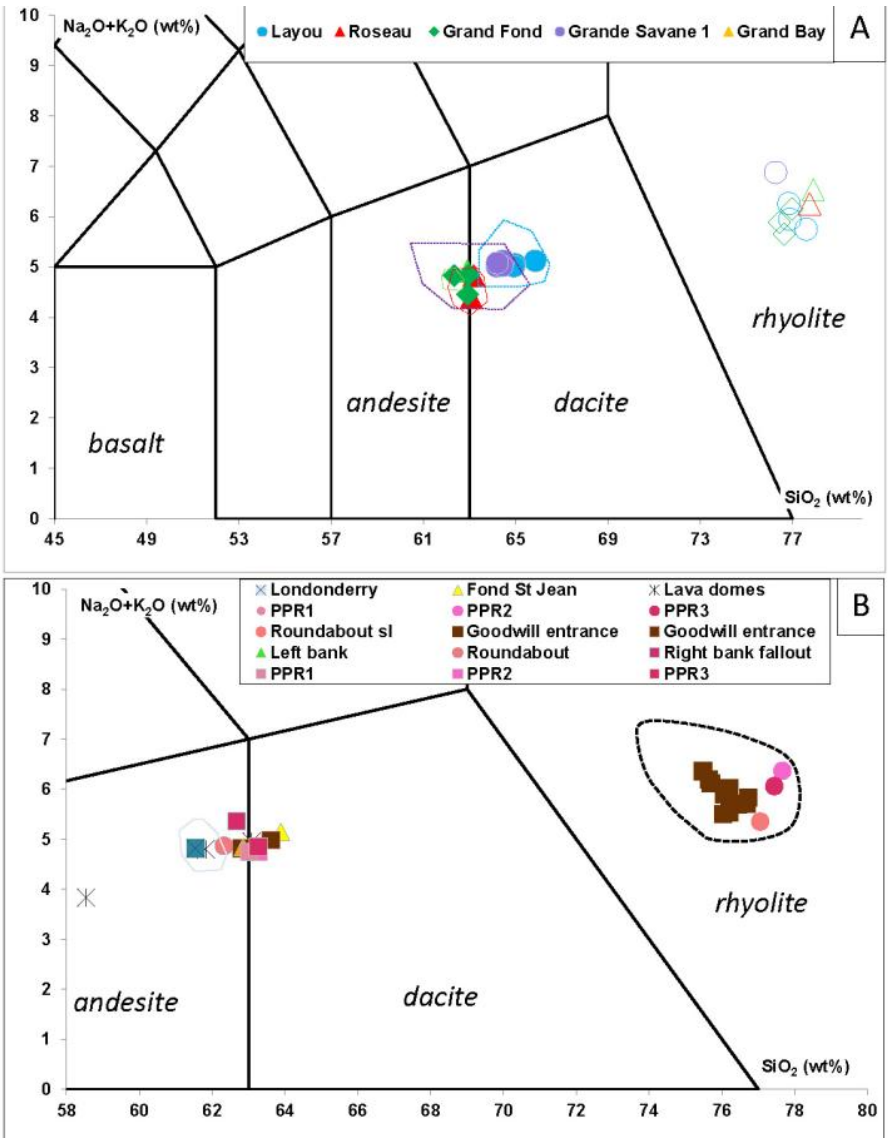

Figure 7 


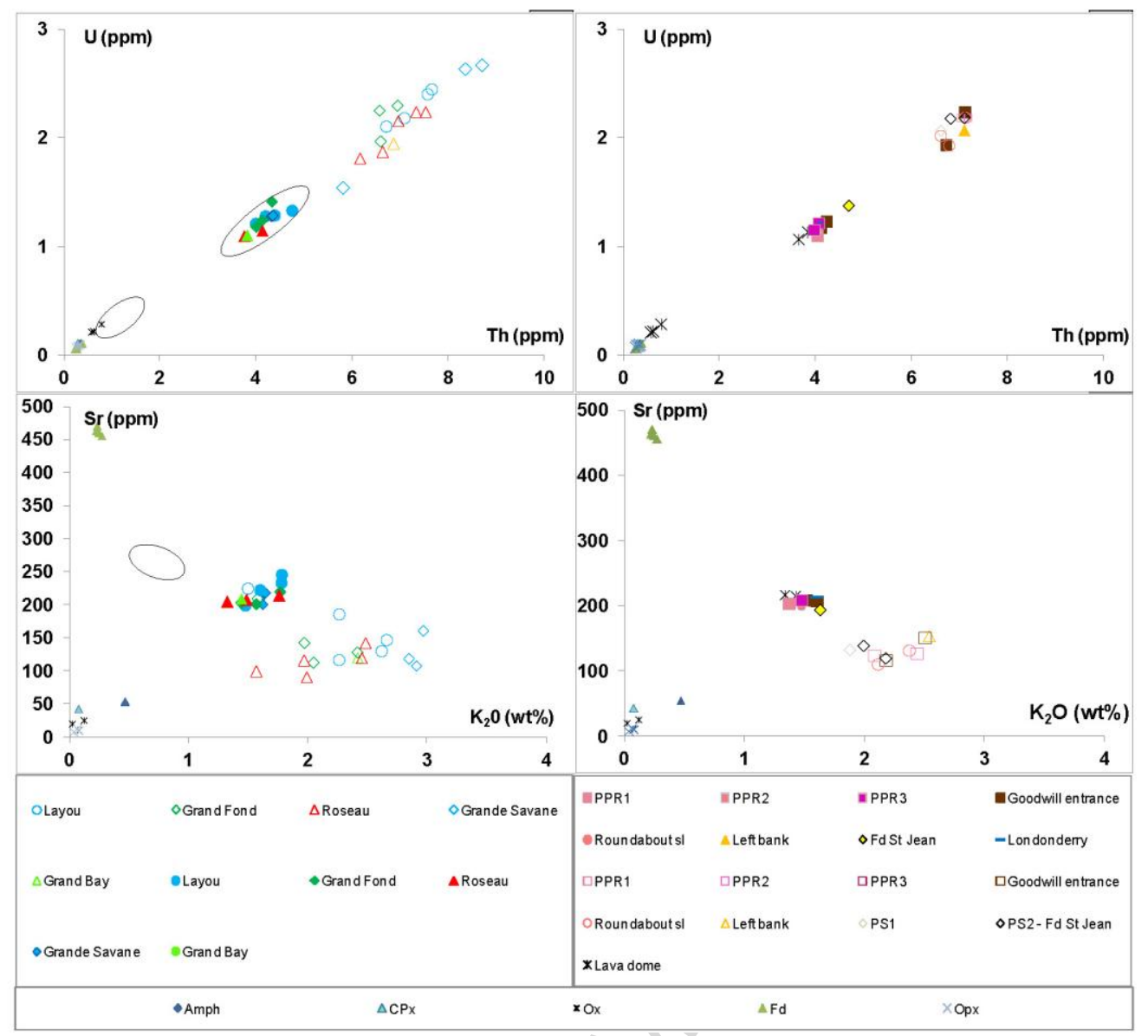

Figure 8 


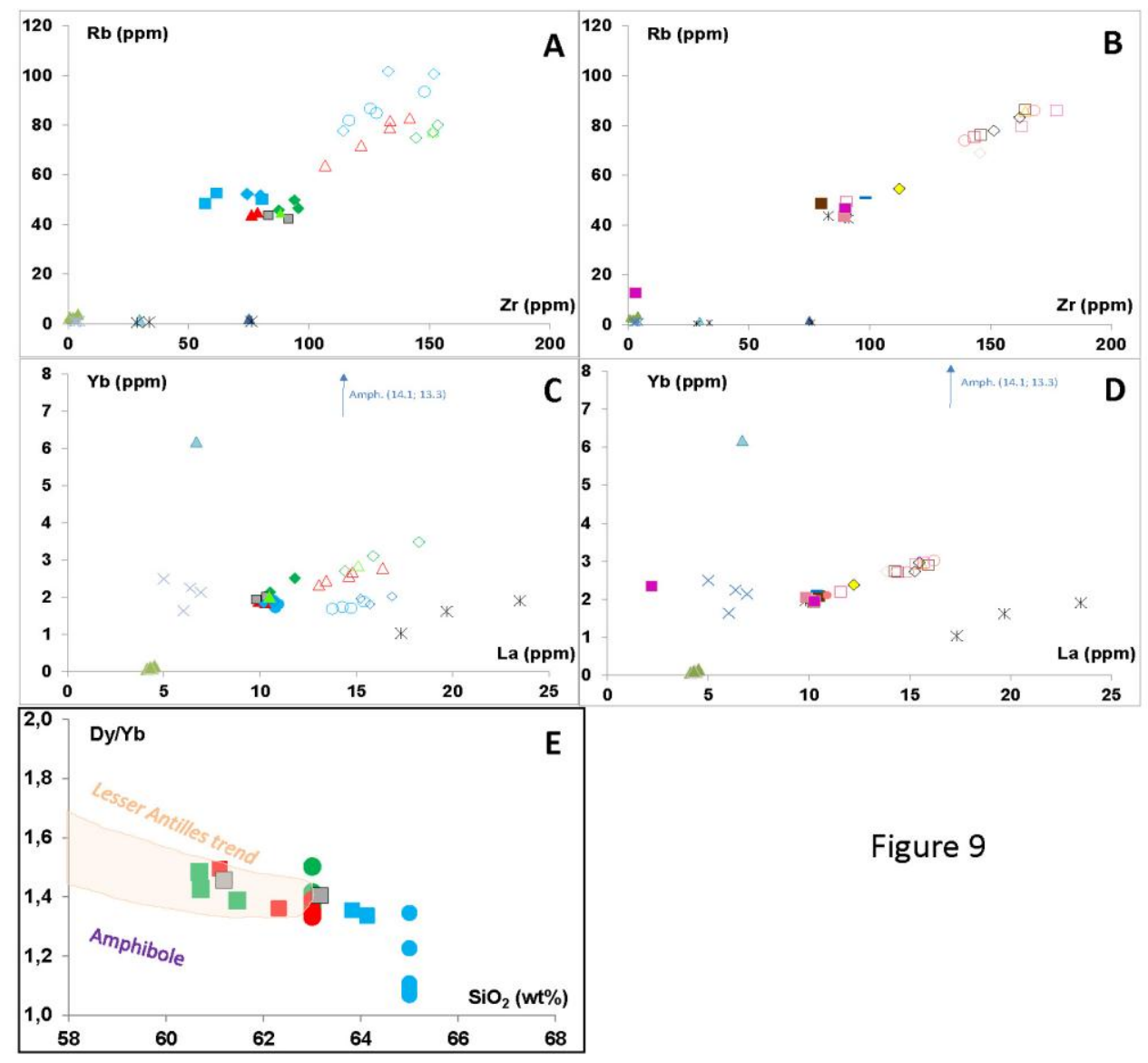




\section{Table 1 : Data synthesis}

\begin{tabular}{|c|c|c|c|c|c|c|c|c|c|c|c|}
\hline \multirow[t]{2}{*}{$\begin{array}{c}\text { Erupt } \\
\text { ive } \\
\text { cente } \\
r\end{array}$} & \multirow[t]{2}{*}{ Name } & \multirow[t]{2}{*}{$\begin{array}{l}\text { Locat } \\
\text { ion }\end{array}$} & \multirow[t]{2}{*}{$\begin{array}{l}\text { Coordin } \\
\text { ates }\end{array}$} & \multirow[t]{2}{*}{$\begin{array}{c}\text { erupti } \\
\text { on } \\
\text { type }\end{array}$} & \multirow[t]{2}{*}{$\begin{array}{l}\text { Depo } \\
\text { sit }\end{array}$} & \multirow{2}{*}{$\begin{array}{l}\text { Dat } \\
\text { es } \\
\text { age }\end{array}$} & \multirow{2}{*}{$\begin{array}{l}\text { lithology } \\
\text { assembly }\end{array}$} & \multicolumn{3}{|c|}{ geochemistry } & \multirow[t]{2}{*}{$\begin{array}{c}\text { correlati } \\
\text { on }\end{array}$} \\
\hline & & & & & & & & $\begin{array}{l}\text { who } \\
\text { le } \\
\text { rock }\end{array}$ & glass & $\begin{array}{c}\text { signat } \\
\text { ure }\end{array}$ & \\
\hline & & & & & & $\begin{array}{l}\text { yrs } \\
c a l \\
B P\end{array}$ & & $\begin{array}{c}\mathrm{SiO} \\
2 \\
w t \%\end{array}$ & $\begin{array}{l}\mathrm{SiO} 2 \\
w t \%\end{array}$ & & \\
\hline \multirow{5}{*}{ 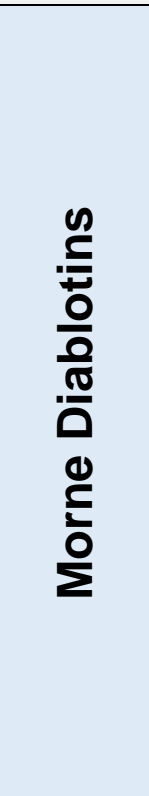 } & Layou & 8 & $\begin{array}{l}15^{\circ} 23 ’ 49 \\
, ' N, \\
61^{\circ} 25^{\prime} 35 \\
, ' \mathrm{~W}\end{array}$ & $\begin{array}{l}\text { ignimb } \\
\text { rite }\end{array}$ & $\begin{array}{l}\text { fallou } \\
t \text { and } \\
\text { flows }\end{array}$ & $\begin{array}{c}50 \\
598 \\
\pm 55 \\
90\end{array}$ & $\begin{array}{c}\mathrm{Fd}+\mathrm{Opx}+\mathrm{Amph}+\mathrm{Ox} \\
+\mathbf{Q z}+\mathrm{Cpx}\end{array}$ & $\begin{array}{c}\text { Dac } \\
\text { ite } \\
63- \\
64\end{array}$ & $\begin{array}{c}\text { Rhyo } \\
\text { lite } \\
77- \\
78\end{array}$ & $\begin{array}{c}\text { high } \\
\mathrm{Rb} / \mathrm{Zr}\end{array}$ & GS1 \\
\hline & & & & & & & & & & $\begin{array}{l}\text { Yb } \\
\text { app. }\end{array}$ & \\
\hline & $\begin{array}{c}\text { Grande } \\
\text { Savane } \\
1\end{array}$ & 10 & $\begin{array}{l}15^{\circ} 26^{\prime} 09 \\
, " N, \\
61^{\circ} 26^{\prime} 21 \\
{ }^{\prime} \mathrm{W}\end{array}$ & $\underset{\text { rite }}{\text { ignimb }}$ & $\begin{array}{c}\text { weld } \\
\text { ed } \\
\text { flow }\end{array}$ & $?$ & $\mathrm{Fd}+\mathrm{Opx}+\mathrm{Amph}+\mathrm{Ox}$ & $\begin{array}{c}\text { Dac } \\
\text { ite } \\
63- \\
64\end{array}$ & $\begin{array}{l}\text { Rhyo } \\
\text { lite } \\
76\end{array}$ & $\begin{array}{l}\text { high } \\
\mathrm{Rb} / \mathrm{Zr}\end{array}$ & Layou \\
\hline & (GS1) & & & & & & & & & $\begin{array}{l}\text { Yb } \\
\text { app. }\end{array}$ & \\
\hline & $\begin{array}{l}\text { Grande } \\
\text { Savane }\end{array}$ & 10 & & & $\begin{array}{c}\text { fallou } \\
t\end{array}$ & $\begin{array}{l}>22 \\
000\end{array}$ & $\mathrm{Fd}+\mathrm{Opx}+\mathrm{Cpx}+\mathrm{Ox}$ & n.d. & & & \\
\hline
\end{tabular}




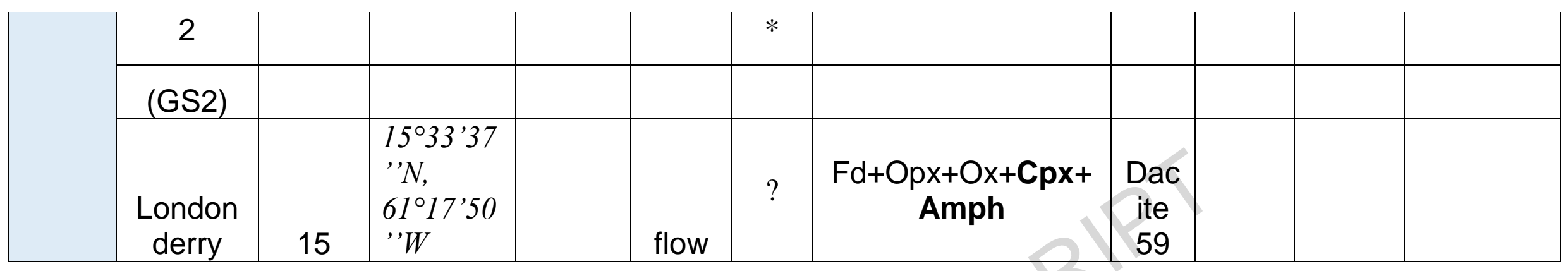

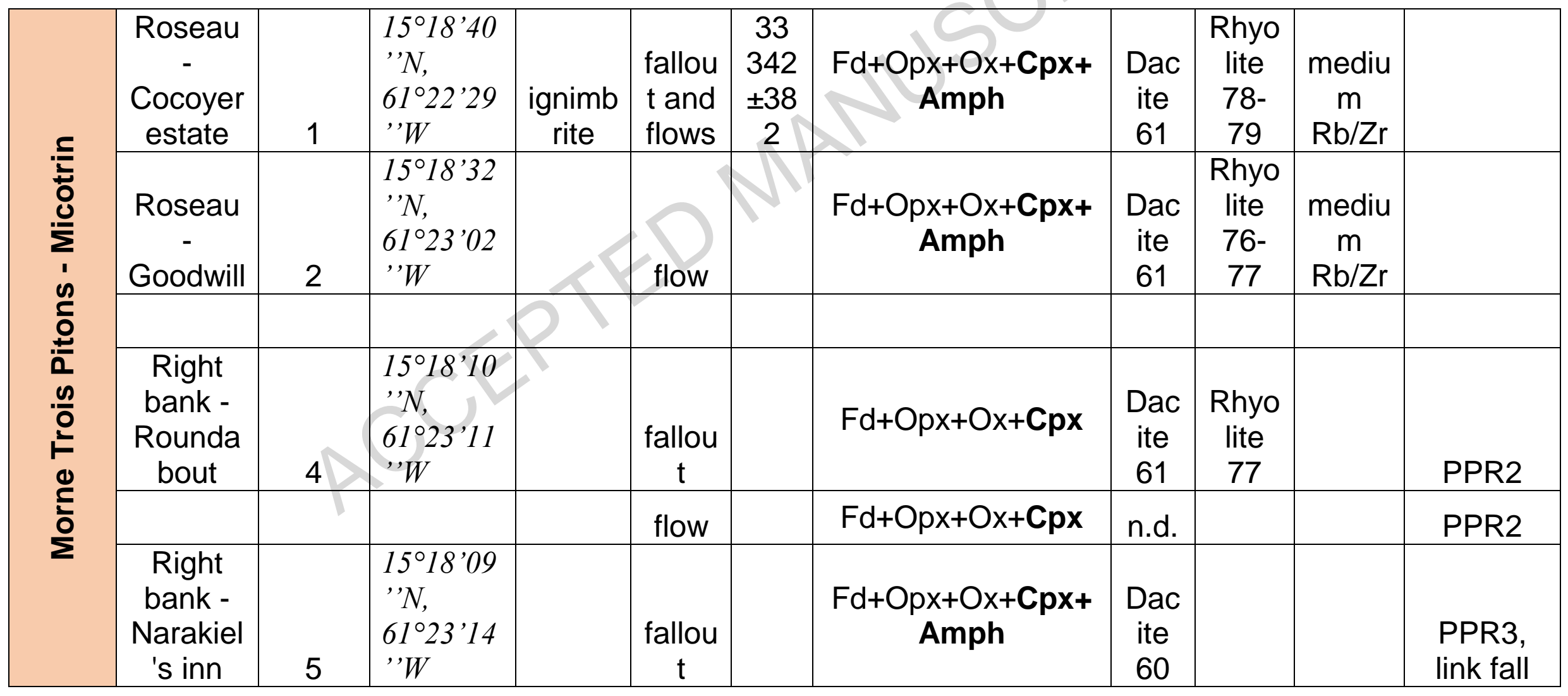




\begin{tabular}{|c|c|c|c|c|c|c|c|}
\hline & & & flow & & $\mathrm{Fd}+\mathrm{Opx}+\mathrm{Ox}+\mathrm{Cpx}$ & n.d. & $\begin{array}{c}\text { Roundab } \\
\text { out1, } 2, \\
\text { Link Flow } \\
2\end{array}$ \\
\hline $\begin{array}{l}\text { Link } \\
\text { road }\end{array}$ & 6 & $\begin{array}{l}15^{\circ} 18^{\prime} 15 \\
,{ }^{\prime} \mathrm{,} \\
61^{\circ} 222^{\prime} 34 \\
,{ }^{\prime} \mathrm{W}\end{array}$ & $\begin{array}{l}\text { link } \\
\text { flow1 }\end{array}$ & & $\mathrm{Fd}+\mathrm{Opx}+\mathrm{Ox}+\mathrm{Cpx}$ & n.d. & $\begin{array}{c}\text { Goodwill } \\
\text { entrance- } \\
\text { Link flow } \\
1\end{array}$ \\
\hline & & & $\begin{array}{l}\text { ash } \\
\text { flow } \\
1\end{array}$ & & & n.d. & \\
\hline & & & $\begin{array}{l}\text { ash } \\
\text { flow } \\
2\end{array}$ & & & n.d. & \\
\hline & & & $\begin{array}{l}\text { link } \\
\text { flow } \\
2\end{array}$ & & $\mathrm{Fd}+\mathrm{Opx}+\mathrm{Ox}+\mathrm{Cpx}$ & n.d. & PPR2 \\
\hline & & & $\begin{array}{l}\text { link } \\
\text { fall }\end{array}$ & & $\begin{array}{c}\mathrm{Fd}+\mathrm{Opx}+\mathrm{Ox}+\mathrm{Cpx}+ \\
\text { Amph }\end{array}$ & n.d. & $\begin{array}{c}\text { Right } \\
\text { bank - } \\
\text { Narakiel' } \\
\text { s inn flow }\end{array}$ \\
\hline $\begin{array}{c}\text { Left } \\
\text { bank - } \\
\text { Lacorne }\end{array}$ & 7 & $\begin{array}{l}15^{\circ} 18^{\prime} 29 \\
,{ }^{\prime}, \\
61^{\circ} 211^{\prime} 48 \\
,{ }^{\prime} W\end{array}$ & flow & $\begin{array}{l}32 \\
037 \\
\pm 51 \\
9\end{array}$ & $\mathrm{Fd}+\mathrm{Opx}+\mathrm{Ox}+\mathrm{Cpx}$ & $\begin{array}{c}\text { Dac } \\
\text { ite } \\
62\end{array}$ & $\begin{array}{c}\text { Link flow } \\
1\end{array}$ \\
\hline
\end{tabular}




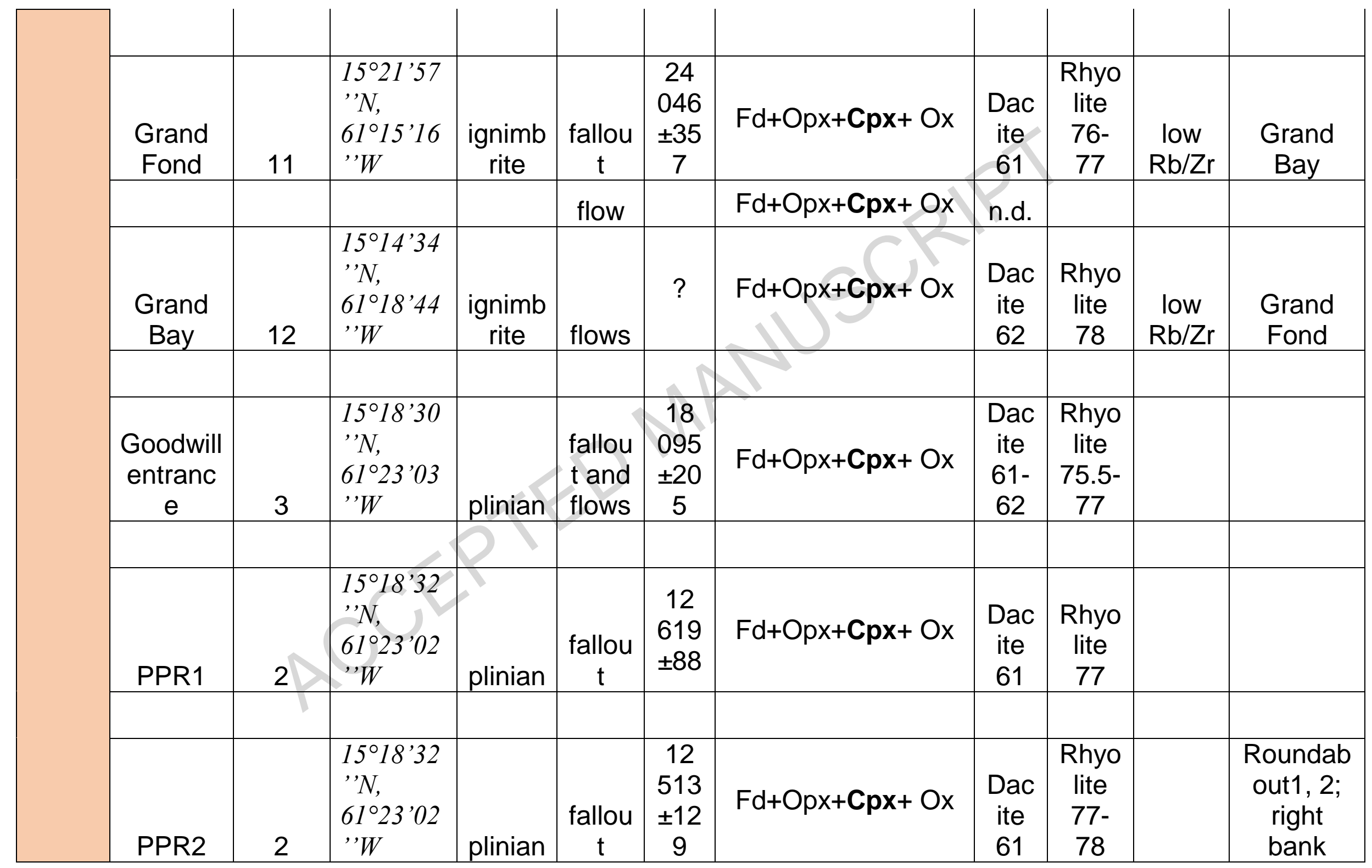




\begin{tabular}{|c|c|c|c|c|c|c|c|c|c|}
\hline & & & & & & & & & $\begin{array}{l}\text { flow; Link } \\
\text { flow } 2\end{array}$ \\
\hline PPR3 & 2 & $\begin{array}{l}15^{\circ} 18^{\prime} 32 \\
,{ }^{\prime}, \\
61^{\circ} 23^{\prime} 02 \\
{ }^{\prime} \mathrm{W}\end{array}$ & plinian & $\begin{array}{c}\text { fallou } \\
t\end{array}$ & $\begin{array}{c}9 \\
391 \\
\pm 94\end{array}$ & $\begin{array}{c}\mathrm{Fd}+\mathrm{Opx}+\mathrm{Ox}+\mathrm{Cpx}+ \\
\text { Amph }\end{array}$ & $\begin{array}{l}\text { Dac } \\
\text { ite } \\
61\end{array}$ & $\begin{array}{l}\text { Rhyo } \\
\text { lite } \\
77- \\
78\end{array}$ & $\begin{array}{c}\text { right } \\
\text { bank } \\
\text { fallout; } \\
\text { link } \\
\text { fallout }\end{array}$ \\
\hline
\end{tabular}

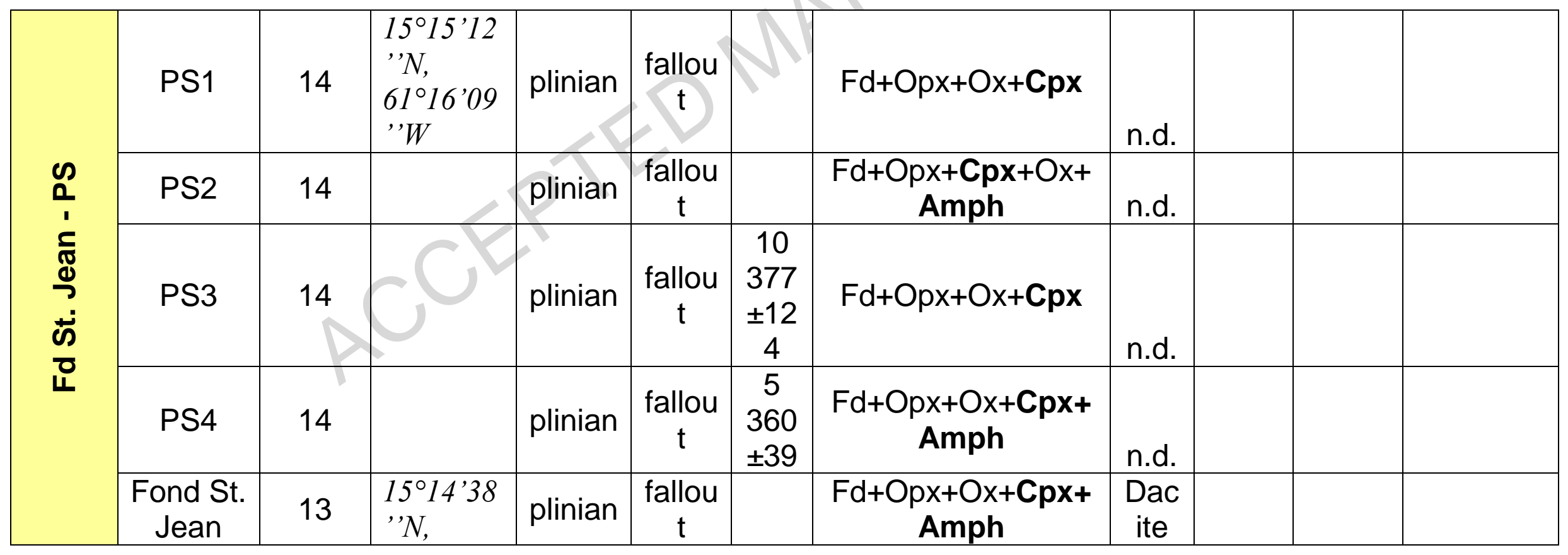




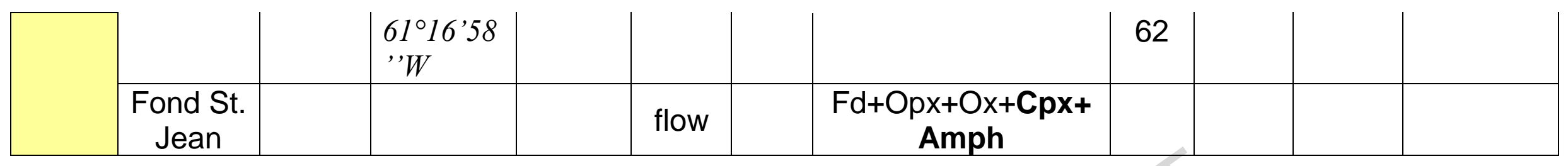


Table 2: Lithology - signature $n=$ number of counting.

\begin{tabular}{|c|c|c|c|c|c|c|c|c|}
\hline \multirow{2}{*}{$\begin{array}{c}\text { Deposit } \\
\text { type }\end{array}$} & \multicolumn{4}{|c|}{ Layou } & \multicolumn{4}{|c|}{ Grande Savane } \\
\hline & \multicolumn{2}{|c|}{ Fallout } & \multicolumn{2}{|c|}{ Flow } & \multicolumn{2}{|c|}{ Flow - Unit 1} & \multicolumn{2}{|c|}{ Flow - Unit 2} \\
\hline $\mathrm{n}$ & \multicolumn{2}{|c|}{2} & \multicolumn{2}{|c|}{3} & \multicolumn{2}{|c|}{2} & \multicolumn{2}{|c|}{2} \\
\hline & mean (\%) & $\sigma(\%)$ & mean (\%) & $\sigma(\%)$ & mean (\%) & $\sigma(\%)$ & mean (\%) & $\sigma(\%)$ \\
\hline feldspar & 57 & 7 & 72 & 1 & 78 & 2 & 79 & 3 \\
\hline orthopyroxene & 23 & 6 & 11 & 2 & 10 & 2 & 15 & 2 \\
\hline clinopyroxene & 1 & 1 & 0 & 0 & 0 & 2 & 4 & 1 \\
\hline amphibole & 13 & 0 & 13 & 2 & 10 & 1 & 0 & 0 \\
\hline oxyde & 5 & 1 & 2 & 1 & 1 & 1. & 3 & 0 \\
\hline quartz & 2 & 0 & 1 & 0 & 0 & 0 & 0 & 0 \\
\hline
\end{tabular}

\begin{tabular}{|c|c|c|c|c|c|c|c|c|c|c|c|c|}
\hline \multirow{4}{*}{$\begin{array}{c}\text { Deposit } \\
\text { type } \\
\mathrm{n} \\
\end{array}$} & \multicolumn{4}{|c|}{ Roseau } & \multicolumn{4}{|c|}{ Grand Fond } & \multicolumn{4}{|c|}{ Grand Bay } \\
\hline & \multirow{2}{*}{\multicolumn{2}{|c|}{$\begin{array}{c}\text { Fallout } \\
3\end{array}$}} & \multirow{2}{*}{\multicolumn{2}{|c|}{$\begin{array}{c}\text { Flow } \\
4\end{array}$}} & \multirow{2}{*}{\multicolumn{2}{|c|}{$\frac{\text { Fallout }}{2}$}} & \multirow{2}{*}{\multicolumn{2}{|c|}{$\begin{array}{c}\text { Flow } \\
1\end{array}$}} & \multicolumn{2}{|c|}{ Fallout } & \multirow{2}{*}{\multicolumn{2}{|c|}{$\begin{array}{c}\text { Flow } \\
4\end{array}$}} \\
\hline & & & & & & & & & & & & \\
\hline & mean (\%) & $\sigma(\%)$ & mean $(\%)$ & $\sigma(\%)$ & mean (\%) & $\sigma(\%)$ & mean $(\%)$ & $\sigma(\%)$ & mean (\%) & $\sigma(\%)$ & mean (\%) & $\sigma(\%)$ \\
\hline orthopyroxene & 25 & 1 & 16 & 0 & 26 & 3 & 23 & & & & 21 & 5 \\
\hline clinopyroxene & 3 & 1 & 2 & 2 & 5 & 1 & 3 & & & & 7 & 2 \\
\hline quartz & 0 & 0 & 0 & 0 & 0 & 0 & 0 & & & & 2 & 3 \\
\hline
\end{tabular}


Highlights

- We have precised the stratigraphy relative to the explosive activity in Dominica in the last tens of thousands years

- Repetitive Plinian eruptions occurs in addition to large ignimbritic eruptions

- We emphasize the importance of using glass geochemistry

- We precise the eruptive center 